\title{
New data about the diversity of Early Oligocene eomyids (Mammalia, Rodentia) in Western Europe
}

\author{
Olivier MARIDET \\ Key Laboratory of Evolutionary Systematics of Vertebrates, \\ Institute of Vertebrate Paleontology and Paleoanthropology, \\ Chinese Academy of Sciences, \\ \#142, Xizhimenwai Dajie, P.O. Box 643, Beijing 100044 (China) \\ olivier.maridet@ivpp.ac.cn \\ Marguerite HUGUENEY \\ UMR 5125 PEPS-CNRS-UCBL, \\ Domaine scientifique de la DOUA, Bât. GEODE, \\ 2 rue Dubois, F-69622 Villeurbanne Cedex (France) \\ marguerite.hugueney@univ-lyon1.fr \\ Kurt HEISSIG \\ Department für Geo- und Umwelt-Wissenschaften-Section Paläontologie, \\ Ludwig-Maximilians Universität, \\ Richard-Wagner-Str. 10, G-80333 München (Germany) \\ k.heissig@Irz.uni-muenchen.de
}

KEY WORDS

Mammalia,

Rodentia,

Eomyidae, Eomys,

Early Oligocene, Europe,

Germany, France, Spain, migrations.
Maridet O., Hugueney M. \& Heissig K. 2010. - New data about the diversity of Early Oligocene eomyids (Mammalia, Rodentia) in Western Europe. Geodiversitas 32 (2): 221-254.

\section{ABSTRACT}

New material of eomyids from the very Early Oligocene of southern Germany and the late Early Oligocene of France and Spain has been studied. In Germany besides the previously known and unique Eomys antiquus (Aymard, 1853), two other species have been found including an undetermined genus, Eomyidae gen. et sp. indet, with unexpected morphological features that were considered as derived based on our current knowledge. These three species show that at least three immigrant lineages were present as early as the beginning of the Oligocene in Europe. In France and Spain, except for Eomys antiquus which confirms its large geographical distribution, the species found are unlikely to have evolved from the German ones, thus suggesting another immigration wave of eomyids in Europe. Finally, the diversity of the first European eomyids is higher than expected, leading us to consider a more complex evolutionary history than a simple radiation from Eomys antiquus as previously proposed. Despite the limited material available, the undetermined genus, here considered as a likely new genus, shows some clear morphological affinities with the Asian late Oligocene genus Asianeomys Wu, Meng, Ye \& Ni, 2006, thus suggesting a possible common Asian ancestor. 


\author{
MOTS CLÉS \\ Mammalia, \\ Rodentia, \\ Eomyidae, \\ Eomys, \\ Oligocène inférieur, \\ Europe, \\ Allemagne, \\ France, \\ Espagne, \\ migrations.
}

\begin{abstract}
RÉSUMÉ
Nouvelles données sur la diversité des eomyidés (Mammalia, Rodentia) de l'Oligocène inférieur d'Europe de l'Ouest.

Du nouveau matériel provenant de l'Oligocène basal du sud de l'Allemagne, et également de la fin de l'Oligocène inférieur de France et d'Espagne a été étudié. En Allemagne, en plus de l'unique espèce déjà connue Eomys antiquus (Aymard, 1853), deux autres espèces ont été trouvées, incluant un genre d'Eomyidae indéterminé, Eomyidae gen. et sp. indet., présentant des caractères morphologiques inattendus qui étaient jusque là considérés comme des caractères dérivés. Ces trois espèces montrent qu'au moins trois lignées différentes sont arrivées en Europe dès le début de l'Oligocène. En France et en Espagne, outre Eomys antiquus qui confirme sa large répartition géographique, les autres espèces trouvées ne semblent pas être les descendantes des espèces d'Allemagne, suggérant une autre phase d'immigration d'Eomyidae plus tardive en Europe. Au final, la diversité des premiers Eomyidae européens est plus importante qu'attendue, amenant à considérer un scénario évolutif plus complexe que celui proposé précédemment, à savoir une radiation unique depuis Eomys antiquus. Malgré le peu de matériel disponible, le genre indéterminé signalé ici comme nouveau présente des affinités morphologiques notables avec le genre Asianeomys Wu, Meng, Ye \& Ni, 2006 connu dans l'Oligocène supérieur d'Asie, suggérant ainsi la possible existence d'un ancêtre commun en Asie.
\end{abstract}

\section{INTRODUCTION}

The family Eomyidae Winge, 1887 is known to appear in Europe after the "Grande Coupure", at the beginning of the Oligocene (MP 21 level). Its Early Oligocene record is rather rare in number of localities as well as in the number of teeth, so that the early development of the family in Europe is not well understood.

The only species known from the Earliest Oligocene is Eomys antiquus Aymard, 1853, described from the locality Ronzon (MP21, central France). Some teeth were also found in several other localities across Europe: Belgium (Fahlbusch 1973), France (Aymard 1853), Germany (Heissig 1987), Spain (Comte \& VianeyLiaud 1989), Switzerland (Engesser 1999) and in Czech Republic where the unique M1/2 from Detan (MP 21) figured by Fejfar (1987) as Eomys cf. zitteli is too small to pertain to this species but corresponds to the smaller dimensions of $E$. antiquus.
Because of its large geographical distribution, E. antiquus is considered as the first eomyid immigrant at the beginning of the Oligocene. Consequently, Fahlbusch $(1973,1979)$ and Comte \& Vianey-Liaud (1989) proposed that most of the late paleogene and neogene eomyids could have evolved from E. antiquus, suggesting a radiation at the beginning of the late Oligocene in Europe.

But other described material points out that the evolutionary history of eomyids for this period remains unclear. In Hoogbutsel (MP 21, Belgium) some teeth larger than those of E. antiquus were described as E. cf. antiquus by Fahlbusch (1973) and several localities from the Early Oligocene molasses of Switzerland and Savoy have provided new material of eomyids, namely $E$. sp 1 from Lovagny (MP 23), E. sp2 and E. sp3 from Bumbach (MP 25) (Engesser \& Mödden 1997) suggesting that the diversity could be higher for this family as early as the beginning of the 
TABLE 1. - Material seen for this publication (in chronological order). The MP levels and the Eomyidae species found are given. * indicates the type material. The levels refer to the Mammalian Reference levels (BiochroM'97 1997).

\begin{tabular}{|c|c|c|}
\hline Locality & Level & Species \\
\hline Gaimersheim & MP 28 & $\begin{array}{l}\text { Eomys zitteli Schlosser, } 1884 \\
\text { Eomys major Freudenberg, } 1941\left(^{*}\right) \\
\text { Eomyodon pusillus (Fahlbusch, } 1969)\left({ }^{*}\right) \\
\text { Eomyodon volkeri Engesser, } 1987\left(^{*}\right)\end{array}$ \\
\hline Treuchtlingen & MP 27 & $\begin{array}{l}\text { Eomys aff. zitteli Schlosser, } 1884 \\
\text { Eomys sp. } \\
\text { Pseudotheridomys sp. }\end{array}$ \\
\hline Burgmagerbein & MP 27 & $\begin{array}{l}\text { Eomys zitteli Schlosser, } 1884 \\
\text { Pseudotheridomys sp.? }\end{array}$ \\
\hline Mas de Pauffié & MP 26 & Eomys zitteli Schlosser, 1884 \\
\hline Oensingen & MP 26 & Eomys molassicus Engesser, 1987 ( ${ }^{\star}$, cast) \\
\hline Bumbach 1 & MP 25 & Eomys nov. sp. 2, 3 - Engesser 1990 (cast) \\
\hline Belgarric & MP 25 & Eomys minor Comte \& Vianey-Liaud, $1987\left(^{*}\right)$ \\
\hline La Blache & MP 24/25 & Eomys minor Comte \& Vianey-Liaud, 1987 \\
\hline Saint-Martin-de-Castillon F & MP 24 & Eomys aff. E. antiquus (Aymard, 1853) \\
\hline Saint-Martin-de-Castillon C & MP 24 & Eomys aff. E. antiquus (Aymard, 1853) \\
\hline Saint-Martin-de-Castillon J & MP 23/24 & Eomys aff. E. zitteli Schlosser, 1884 \\
\hline Saint-Martin-de-Castillon E & MP 23/24 & Eomys aff. E. zitteli Schlosser, 1884 \\
\hline Montalban & MP 23 & Eomys aff. E. antiquus (Aymard, 1853) \\
\hline Lovagny & MP 23 & Eomys nov. sp. 1 - Engesser 1990 \\
\hline Bernloch 1 & MP 23 & Eomys antiquus (Aymard, 1853) (mandible fragment) \\
\hline Möhren 25 & MP 22 & Eomys antiquus (Aymard, 1853) (mandible fragment) \\
\hline Möhren 21 & MP 22 & Eomys antiquus (Aymard, 1853) (mandible fragment) \\
\hline Ronheim & MP 22 & Eomys antiquus (Aymard, 1853) \\
\hline Möhren 13 & MP 22 & $\begin{array}{l}\text { Eomys antiquus (Aymard, 1853) } \\
\text { Eomys sp. }\end{array}$ \\
\hline Ronzon & MP 21 & Eomys antiquus (Aymard, 1853) (*) \\
\hline Möhren 20 & MP 21 & $\begin{array}{l}\text { Eomys antiquus (Aymard, 1853) } \\
\text { Eomys sp. } \\
\text { Eomyidae gen. et sp. indet. }\end{array}$ \\
\hline Möhren 19 & MP 21 & $\begin{array}{l}\text { Eomys antiquus (Aymard, 1853) } \\
\text { Eomys sp. }\end{array}$ \\
\hline
\end{tabular}

Oligocene. Moreover, a new species, E. minor Comte \& Vianey-Liaud, 1987, was described from the locality of Belgarric (Quercy, Southern France, MP 25; Comte \& Vianey-Liaud 1989), and has never been found elsewhere.

Screen-washing in Early Oligocene localities in Germany, France and Spain however yielded more material and made it possible to obtain new populations and to get an idea of morphological and metric variations in these populations. In Germany, three different forms were found as early as the MP 21 level. The French and Spanish levels are a little more recent (MP 23, MP 24) and make it possible to follow the history of the first European eomyids.

\section{MATERIAL AND METHODS}

\section{LOCALITIES STUDIED}

The localities which yielded the eomyid rodents studied here are situated in three different regions.

The localities of Möhren 13, 20, 19, 21, 25, Ronheim and Bernloch are located in Bavaria (Southern Germany). All Möhren localities are fissure fills. Based on previous studies of the faunas (Heissig 1987), Möhren 19 and 20 were attributed to MP 21; Möhren 13, 21, 25 and Ronheim to MP 22 ; Bernloch 1 to MP 23. These localities have provided new eomyid material (only fragmented material for Möhren 21, 25 and Bernloch). The localities Treuchtlingen 1, 
TABLE 2. - Measurements (in mm) of the population of Eomys antiquus (Aymard, 1853) from Möhren 13. Abbreviations: N, number of teeth; Min, minimal value; Max, maximal value; Mean, mean value; SD, standard deviation; CV, coefficient of variation.

\begin{tabular}{|c|c|c|c|c|c|c|c|c|c|c|c|c|}
\hline & \multicolumn{6}{|c|}{ Length } & \multicolumn{6}{|c|}{ Width } \\
\hline & $\mathbf{N}$ & Min & Max & Mean & SD & CV & $\mathbf{N}$ & Min & Max & Mean & SD & CV \\
\hline D4 & 1 & & & 0.68 & & & 1 & & & 0.68 & & \\
\hline P4 & 47 & 0.72 & 0.88 & 0.80 & 0.038 & 4.75 & 47 & 0.75 & 0.90 & 0.83 & 0.038 & 4.58 \\
\hline $\mathrm{M} 1 / 2$ & 85 & 0.86 & 0.99 & 0.91 & 0.033 & 3.63 & 87 & 0.86 & 1.08 & 0.99 & 0.049 & 4.95 \\
\hline M3 & 21 & 0.60 & 0.75 & 0.69 & 0.041 & 5.94 & 21 & 0.75 & 0.90 & 0.83 & 0.043 & 5.18 \\
\hline $\mathrm{d} 4$ & 3 & 0.73 & 0.80 & 0.76 & 0.038 & 5.00 & 3 & 0.60 & 0.63 & 0.61 & 0.014 & 2.30 \\
\hline $\mathrm{p} 4$ & 45 & 0.75 & 0.88 & 0.81 & 0.038 & 4.69 & 46 & 0.63 & 0.80 & 0.74 & 0.038 & 5.14 \\
\hline $\mathrm{m} 1 / 2$ & 61 & 0.84 & 1.10 & 0.97 & 0.049 & 5.05 & 62 & 0.83 & 1.01 & 0.91 & 0.041 & 4.51 \\
\hline $\mathrm{m} 3$ & 53 & 0.80 & 1.00 & 0.88 & 0.042 & 4.77 & 53 & 0.74 & 0.90 & 0.82 & 0.042 & 5.12 \\
\hline
\end{tabular}

TABLE 3. - Measurements (in mm) of the population of Eomys antiquus (Aymard, 1853) from Möhren 20. Abbreviations: N, number of teeth; Min, minimal value; Max, maximal value; Mean, mean value; SD, standard deviation; CV, coefficient of variation.

\begin{tabular}{|c|c|c|c|c|c|c|c|c|c|c|c|c|}
\hline & \multicolumn{6}{|c|}{ Length } & \multicolumn{6}{|c|}{ Width } \\
\hline & $\mathbf{N}$ & Min & Max & Mean & SD & CV & $\mathbf{N}$ & Min & Max & Mean & SD & CV \\
\hline P4 & 7 & 0.77 & 0.85 & 0.80 & 0.025 & 3.12 & 7 & 0.80 & 0.95 & 0.85 & 0.051 & 6.00 \\
\hline M1/2 & 12 & 0.83 & 0.96 & 0.90 & 0.044 & 4.89 & 13 & 0.96 & 1.04 & 1.00 & 0.026 & 2.60 \\
\hline M3 & 2 & 0.70 & 0.72 & 0.71 & - & - & 2 & 0.85 & 0,93 & 0.89 & - & - \\
\hline p4 & 7 & 0.76 & 0.85 & 0.79 & 0.037 & 4.68 & 7 & 0.57 & 0.79 & 0.71 & 0.074 & 10.42 \\
\hline $\mathrm{m} 1 / 2$ & 16 & 0.93 & 1.09 & 1.00 & 0.048 & 4.80 & 16 & 0.84 & 0.99 & 0.90 & 0.048 & 5.33 \\
\hline m3 & 10 & 0.79 & 0.99 & 0.89 & 0.072 & 8.09 & 10 & 0.80 & 0.93 & 0.84 & 0.037 & 4.40 \\
\hline
\end{tabular}

Burgmagerbein and Gaimersheim were studied by Fahlbusch (1970).

In South-Eastern France the Saint-Martin-deCastillon continental deposits (Vaucluse, MP 24) yielded several localities with eomyids (Ducreux et al. 1985; Reichenbacher \& Philippe 1997). These localities show superposed calcareous beds separated by lignitic or detritic clays, thus providing a stratigraphic framework so that their respective age can be established. The older locality is Saint-Martin E, then Saint-Martin J, then Saint-Martin C, the richest one and then Saint-Martin F, the youngest. The Theridomorph rodents (Issiodoromys Bravard, 1852) from $\mathrm{E}$ and $\mathrm{J}$ clearly show that these localities are older than Saint-Martin C and F but a little more recent than Montalban (Hugueney \& Mödden 1996). In the nearby Forcalquier basin, the locality La Blache is approximately of the age of Saint-Martin C or F.

In Spain (Teruel Basin), the Montalban localities are numerous (Freudenthal et al. 1990). The sample studied here comes from the classical level ascribed to MP 23. The list of the localities studied and the material seen for comparisons with the new material is given in Table 1, including the biochronological framework.

\section{TERMinOLOGY}

We follow Engesser (1990) and Wang \& Emry (1991) for the terminology. In addition to this, concerning the description of mesoloph(id)s the term "weak" is used to describe a weakly-developed spur or a crest limited to triangular-shaped bump.

In the following study the number of teeth measured and described do not always fit because some teeth that have been described are not measured because they are partially broken and some teeth that have been measured are too worn on their occlusal surface to be described. All the measurements are given in millimetres. A clear distinction between the first and second molars is possible in less than half of the teeth; for this reason the two teeth are not separated and designed as $\mathrm{M} 1 / 2$ or $\mathrm{m} 1 / 2$. 


\section{ABBREVIATIONS}

\section{Teeth}

A classical eomyid tooth row is composed of four teeth after the diastema: the last premolar and three molars, they are named:

$\begin{array}{ll}\text { P4 } & \text { upper premolar; } \\ \text { M1 } & \text { upper first molar; } \\ \text { M2 } & \text { upper second molar; } \\ \text { M3 } & \text { upper third molar; } \\ \text { p4 } & \text { lower premolar; } \\ \text { m1 } & \text { lower first molar; } \\ \text { m2 } & \text { lower second molar; } \\ \text { m3 } & \text { lower third molar. }\end{array}$

For young individuals a deciduous molar can be found in place of the premolar:

DP4 upper deciduous molar;

dp4 lower deciduous molar.

\section{Institutions}

BSP Bavarian State Collections of Palaeontology, Munich;

FSL Université des Sciences de Lyon;

IVPP Institute of Vertebrate Paleontology and Paleoanthropology, Beijing;

MNHN Muséum national d'Histoire naturelle, Paris; NMB Naturhistorisches Museum, Basel;

USTL Université des Sciences et Techniques du Languedoc, Montpellier.

\section{BIOCHRONOLOGICAL FRAMEWORK}

The biochronological framework used in this study is the "Mammalian Reference levels" established by the International Symposium on Mammalian Biostratigraphy and Paleoecology of the European Palaeogene (Schmidt-Kittler et al. 1987), updated in BiochroM'97 (1997). MP 21 is known as the first biochronological unit of the Oligocene, following in Western Europe the mammalian crisis known as the "Grande coupure" (Stehlin 1910), and characterized by the arrival of new faunas, very likely of Asian origin (eomyids, cricetids). The synchronism of this event in Europe was in debate for a long time (Legendre 1987). However, the discovery in Romania of "post-Grande Coupure cricetids", intercalated in well-dated late Eocene marine series, led Baciu \& Hartenberger (2001) to the conclusion that, in Eastern Europe (Romania) and perhaps also in Southern Germany, asiatic migration events occured earlier. The authors emphasize yet that the "Grande coupure", correlated with the Eocene-Oligocene transition, remains a major change for Western Europe.

\section{SYSTEMATICS}

\author{
Order RODENTIA Bowdich, 1821 \\ Family EOMYIDAE Winge, 1887
}

Genus Eomys Schlosser, 1884

TYPE SPECIES. — Eomys zitteli Schlosser, 1884.

Eomys antiquus (Aymard, 1853)

(Figs $1 ; 2$ )

LeCTOTYPe. - Left mandible with m1-m2, LP R6 (MNHN), designated by Lavocat (1952: pl. 5, fig. 4).

TYPe LOCAlity. - Ronzon (France).

OtHeR STUdied LOCALITIES. - German localities: Ronheim, Möhren 19, 13, 20, only mandibles fragments for Bernloch 1, Möhren 21, 25.

TEETH SIZE. - In the earliest localities, three different species of eomyids can be identified based on size, a small one and two larger ones. We describe the small species first, that has been found in all the localities from the Early Oligocene generally with an abundant material. Measurements for specimen from the localities Möhren 13 and Möhren 20 are given in Tables 2; 3 and Figure 3.

Ronheim - M1/2: $0.87 \times 0.93 \mathrm{~mm}$;

Möhren 19-M1/2: $1.01 \times 1.10$; P4: $0.79 \times 0.93 \mathrm{~mm}$.

\section{DESCRIPTION}

P4

The labial anteroloph is generally well developed, sometimes even disconnected from the protoloph, providing a short, isolated labial fore-crest. On some teeth it may also be weakly developed or even absent. The lingual anteroloph is not clearly developed, usually limited to a weak fold of the enamel suggesting the formation of a crest. On one tooth in Möhren 13 the protoloph is absent and the paracone is disconnected from protocone (Fig. 1G; Appendix Fig. A1-Rare morphologies).

The mesoloph also has a noticeable variability, it can be absent, weak or short. The entoloph is usually continuous, but can sometimes be broken 


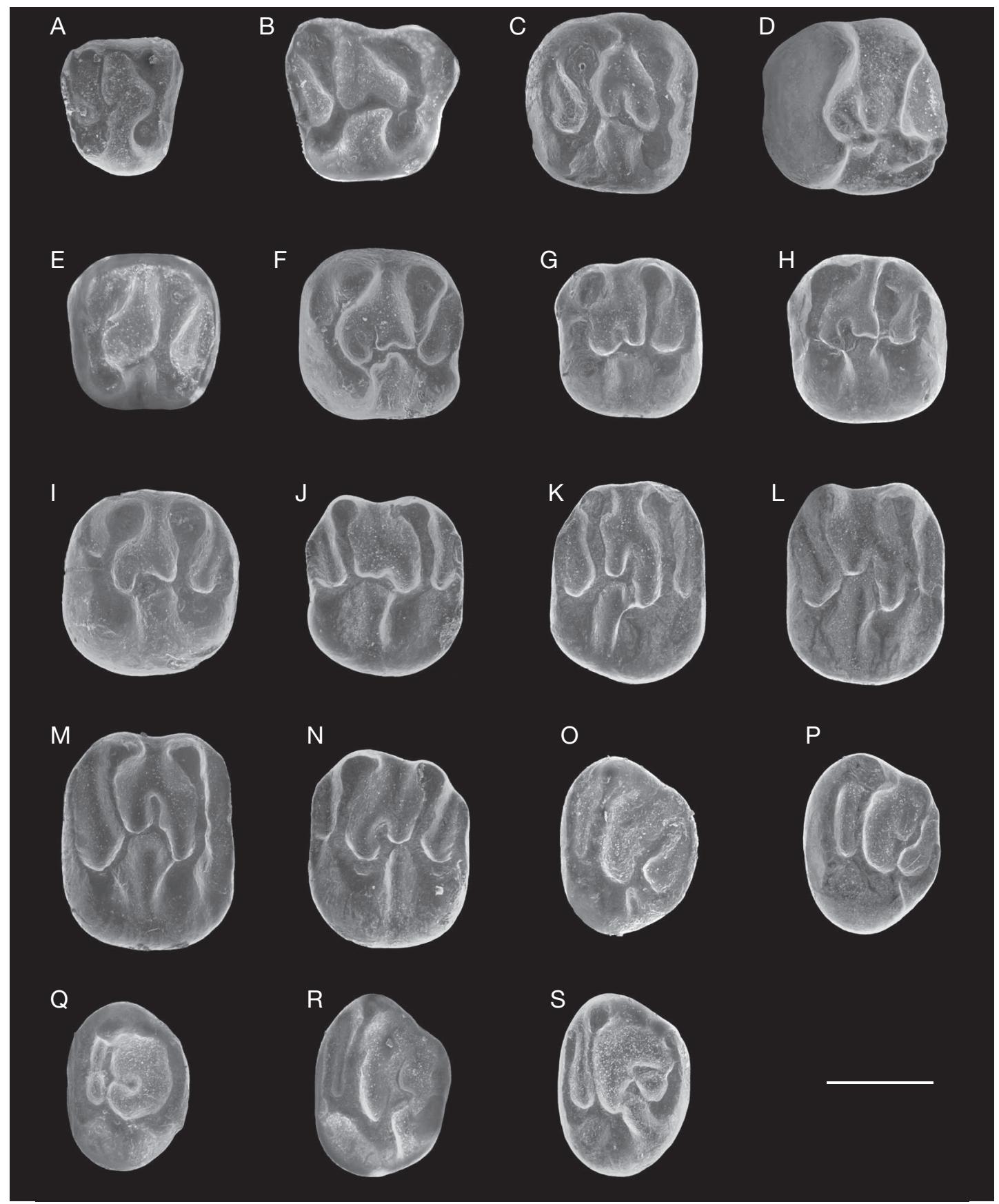

FIG. 1. - Eomys antiquus (Aymard, 1853) upper teeth, Möhren 13: A, RDP4, BSP 1972 XI 4263; B, RP4, BSP 1972 XI 3908; C, RP4, BSP 1972 XI 3920; D, LP4, BSP 1972 XI 3931; E, LP4, BSP 1972 XI 3926; F, LP4, BSP 1972 XI 3911; G, LP4, BSP 1972 XI 3945; H, LP4, BSP 1972 XI 3947; I, LP4, BSP 1972 XI 3909; J, RM1/2, BSP 1972 XI 4020; K, RM2, BSP 1972 XI 3949; L, RM1/2, BSP 1972 XI 3950; M, RM1/2, BSP 1972 XI 4023; N, LM2, BSP 1972 XI 3999; O, LM3, BSP 1972 XI 4041; P, LM3, BSP 1972 XI 4043; Q, LM3, BSP 1972 XI 4047; R, LM3, BSP 1972 XI 4052; S, LM3, BSP 1972 XI 4038. Scale bar: 0.5 mm. 


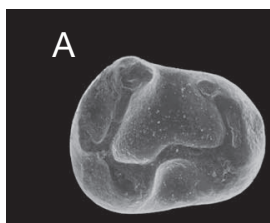

B

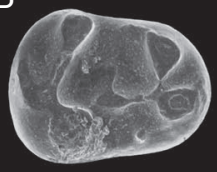

E

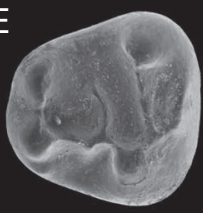

I

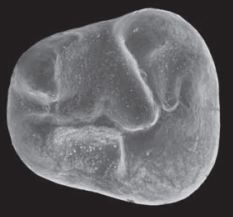

F

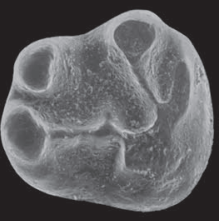

J

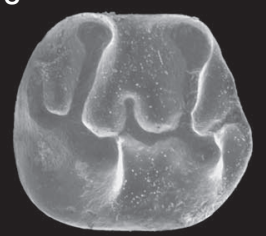

C

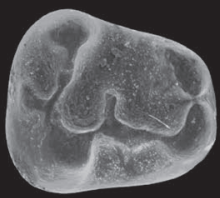

G

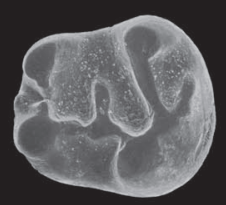

K

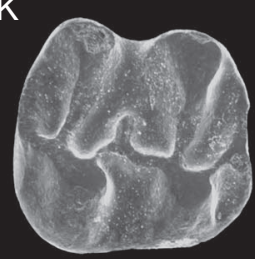

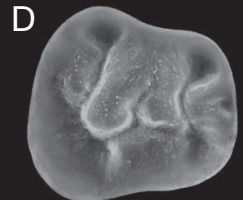

$\mathrm{H}$

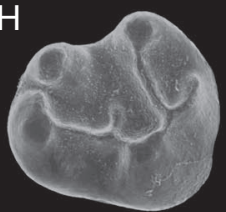

L

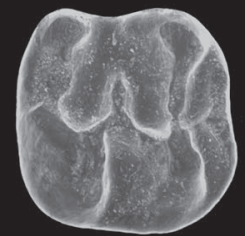

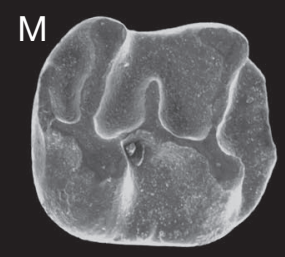
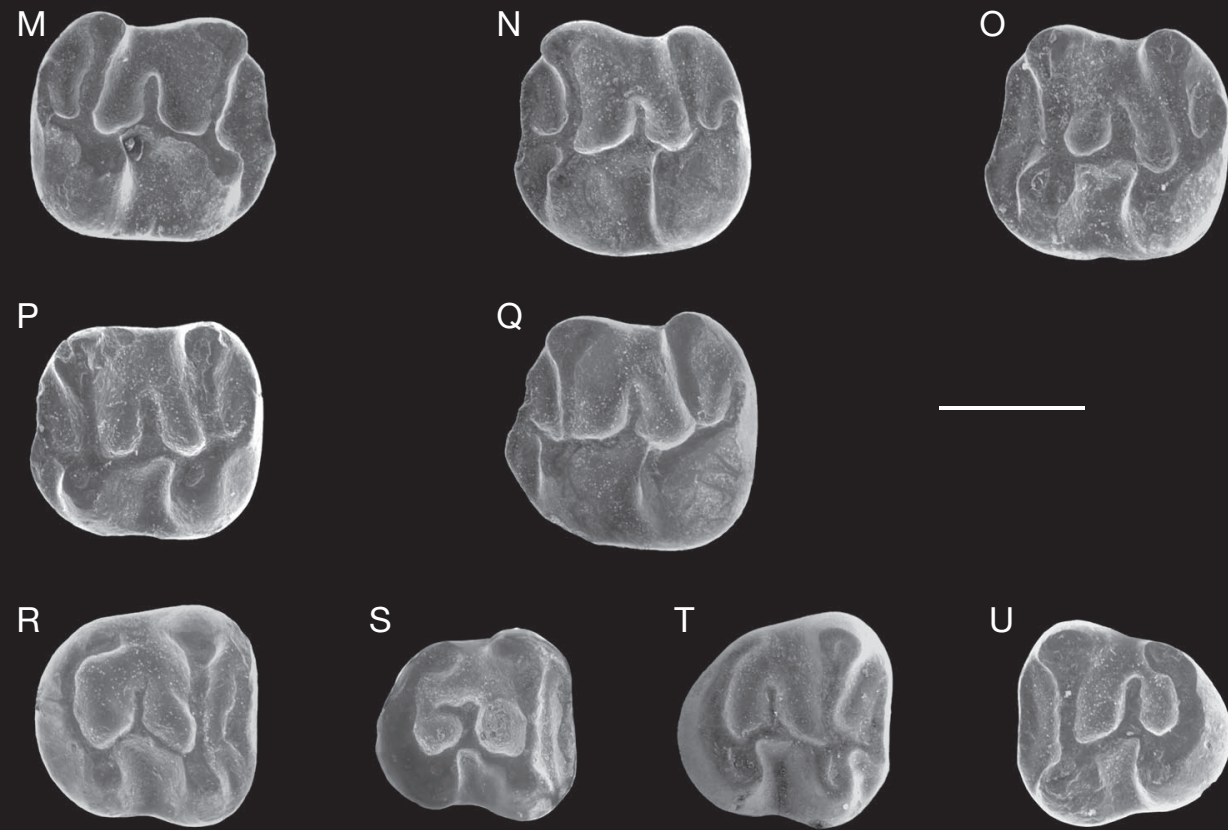

S

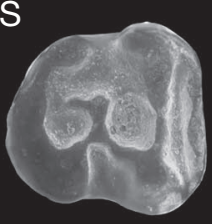

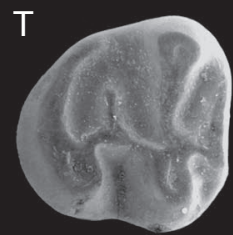

U

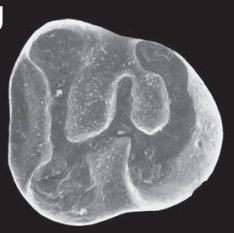

FIG. 2. - Eomys antiquus (Aymard, 1853) lower teeth, Möhren 13: A, Rdp4, BSP 1972 XI 4261; B, Rdp4, BSP 1972 XI 4262; C, Rp4, BSP 1972 XI 4082; D, Rp4, BSP 1972 XI 4098; E, Lp4, BSP 1972 XI 4074; F, Lp4, BSP 1972 XI 4058; G, Lp4, BSP 1972 XI 4059; H, Lp4, BSP 1972 XI 4060; I, Lp4, BSP 1972 XI 4064; J, Rm1/2, BSP 1972 XI 4122; K, Rm1, BSP 1972 XI 4135; L, Rm1/2, BSP 1972 XI 4133; M, Rm1/2, BSP 1972 XI 4148; N, Lm2, BSP 1972 XI 4171; O, Lm2, BSP 1972 XI 4196; P, Lm1/2, BSP 1972 XI 4135; Q, Lm1, BSP 1972 XI 4118; R, Rm3, BSP 1972 XI 4210; S, Rm3, BSP 1972 XI 4245; T, Rm3, BSP 1972 XI 4251; U, Lm3, BSP 1972 XI 4232. Scale bar: 0.5 mm. 
between the mesoloph and the protocone or between the mesoloph and the hypocone. Only one tooth in Möhren 13 presents a clearly developed lingual posteroloph (Fig. 1D).

\section{$M 1 / 2$}

The labial anteroloph is long, starting at the base of the protoloph, generally on a distinct anterocone. The lingual anteroloph is generally absent except in some cases with a weakly or clearly developed lingual anteroloph. Some teeth from Möhren 13 and Möhren 20 have the two anterolophs disconnected from the protoloph, thus leading to the separation of a long, isolated fore-crest. The mesoloph is generally short and curved backwards, but it can be oblique to the front of the tooth. Some teeth have a special morphology of the mesoloph indicating a trend to the presence of a second mesoloph (Appendix Fig. A2-I), as is the case in the Eocene Symplokeomys zaysanicus Emry \& Wang, 1997 from Kazakhstan (Emry et al. 1997).

The entoloph is generally continuous, but can also be discontinuous, broken between the mesoloph and the protocone or between the mesoloph and the hypocone.

\section{M3}

The general shape of these teeth is rounded, with a short posterior part. In the anterior part, a short and weakly-developed lingual anteroloph can be observed on some teeth. One tooth also has a posterior spur on the protoloph (Fig. 1Q; Appendix Fig. A3-Rare morphologies).

The morphological variability is higher in the posterior part of teeth. The metaloph is usually completely developed, reaching the labial border but it can also be short or absent.

A forward crest can start from the metaloph. It can be short or reaching the labial border of the tooth, and in some rare cases, connected to the protoloph. A backward crest can also appear, linking the metaloph and the posteroloph. One tooth in Möhren 13 also presents posterior spur starting from the protoloph (Fig. 1Q).

\section{p4}

The anterior part is always divided in two tubercles that can be interpreted as protoconid and metaco- nid. The two tubercles are usually clearly separated or almost joining each other, few are linked by a transverse crest or linked backward on the ectolophid. A third and smaller cuspid, connected to the protoconid and corresponding to the anteroconid, can sometimes be observed.

The mesolophid is generally short but can also be absent, weak or rarely reaching the lingual border. In the posterior part, the posterolophid is usually weakly developed and closely positioned to the hypolophid delimiting a narrow posterosinus, but more rarely is well developed. The ectolophid can also be discontinuous.

\section{$m 1 / 2$}

The labial and lingual anterolophids are generally both well developed. The labial one can be shorter or even absent. The antero-labial part of the tooth is rounded due to the strong development of the labial anterolophid. The shape of the protoconid is variable, generally oriented forward, but sometimes more perpendicular to the tooth axis or even oriented backward.

The anterolophids are generally connected to the protoconid but can also be connected to the metalophulid or disconnected. The mesolophid has less variability, generally of average size, very rarely weak. Some rare teeth lack the posterolophid as is the case on the $\mathrm{m} 2$ of the type mandible of E. antiquus.

\section{m3}

The labial and lingual anterolophids are both well developed, their connection can be with the protoconid or with the metalophid, or they can be disconnected. The shape of the protoconid also has the same variability as in $\mathrm{m} 1 / 2$.

The mesolophid is always well developed but rarely reaching the lingual side of the tooth. The ectolophid is usually continuous, but it can be broken between the mesolophid and the hypoconid.

On some rare teeth, a longitudinal spur can appear between the posterolophid and the mesolophid, starting from the mesolophid or from the posterolophid. This spur can be weakly developed or well developed almost linking the mesolophid and the posterolophid. 


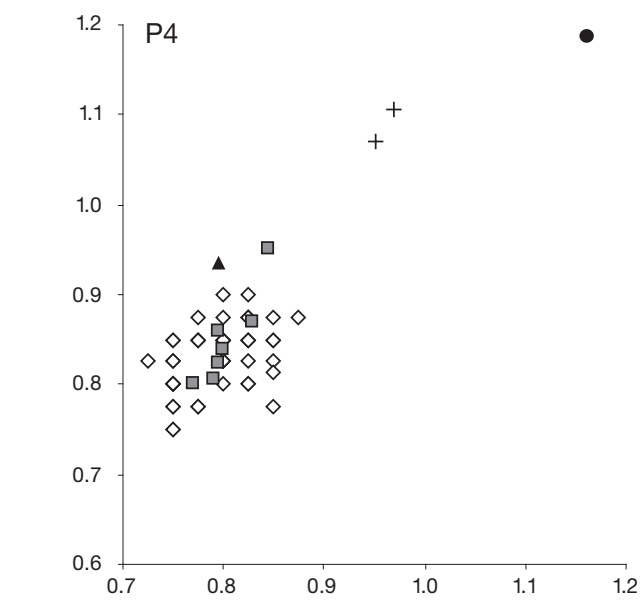

\begin{tabular}{|c|c|}
\hline Eomys antiquus & Eomys sp. \\
\hline$\square$ Möhren 20 & + Möhren 20 \\
\hline A Möhren 19 & × Möhren 19 \\
\hline$\diamond$ Möhren 13 & Eomyidae gen. et sp. indet. \\
\hline$\star$ Ronzon & - Möhren 20 \\
\hline
\end{tabular}
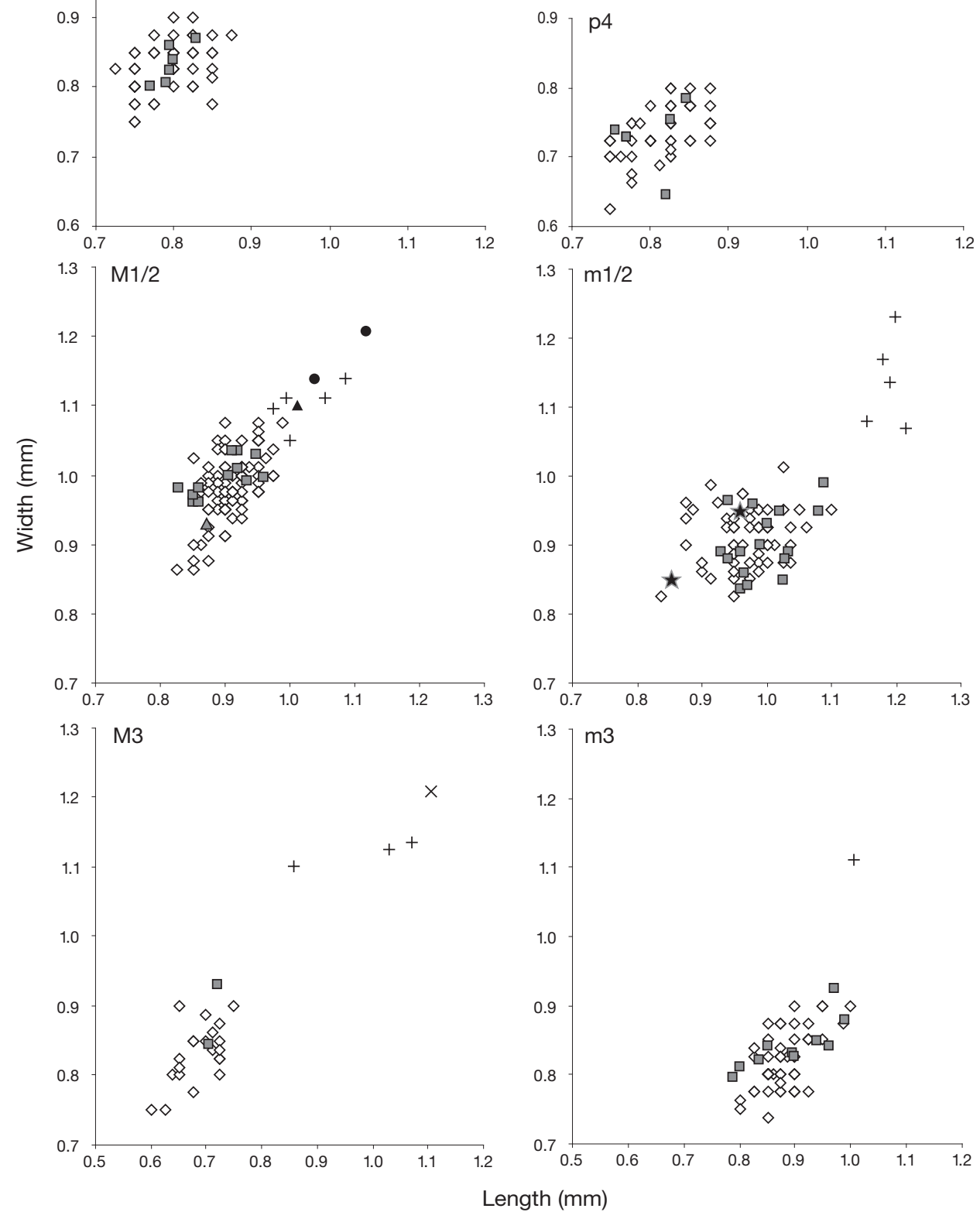

FIG. 3. - Comparison of size for the three species yielded by German localities. The sizes of the two teeth from the type locality of Eomys antiquus (Aymard, 1853), Ronzon, are indicated by stars. 


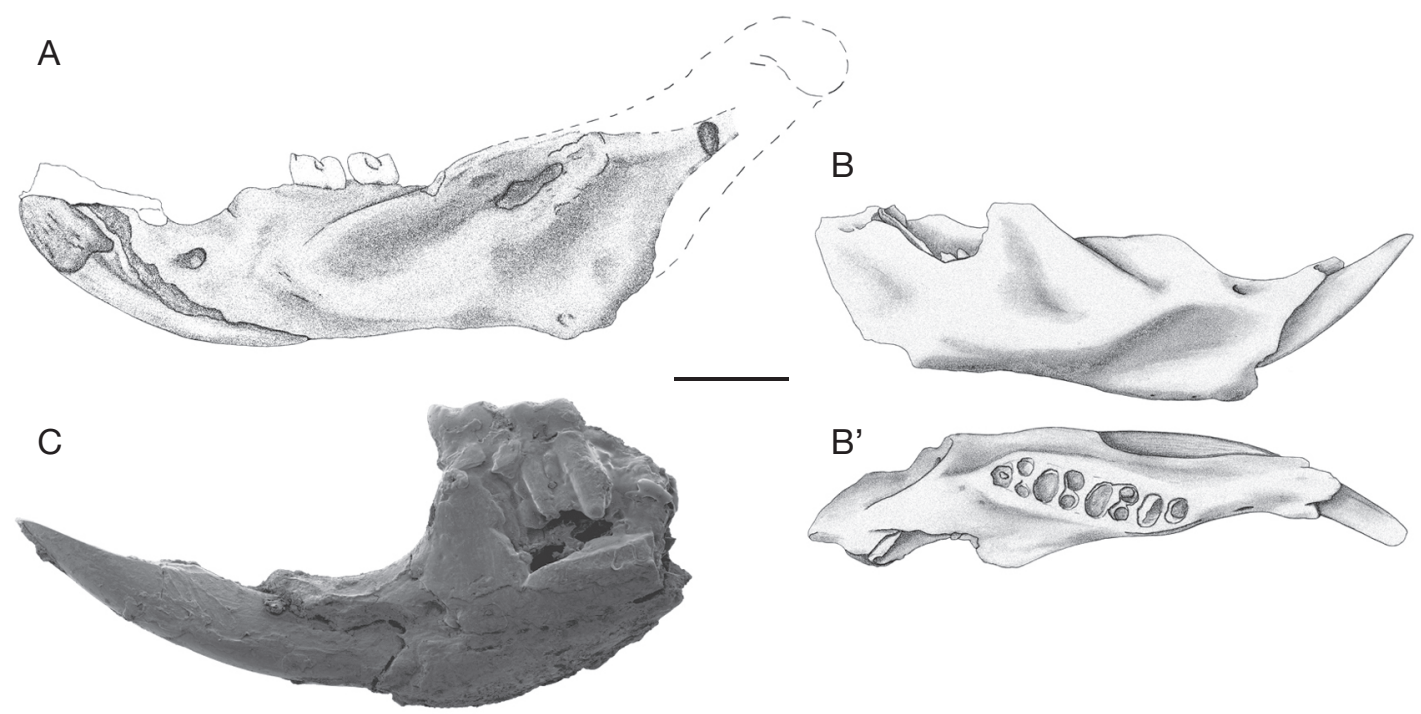

FIG. 4. - Comparison of the mandibles of Eomys antiquus (Aymard, 1853) and Eomys aff. E. zitteli Schlosser, 1884: A, left mandible of Eomys antiquus from Ronzon in labial view, type material (drawing based on a cast MNHN, upper view cannot be observed); B, right mandible of Eomys antiquus from Möhren 13 (BSP 1972 XI 4270); B, labial view; B', upper view; C, left mandible of Eomys aff. E. zitteli from Saint-Martin-de-Castillon E (FSL 98181). Scale bar: $2 \mathrm{~mm}$.

\section{DP4 and $d p 4$}

Very few teeth with a very simple morphology have been found in Möhren 13 and 20. Those teeth have a premolar-type morphology but can be easily differentiated by their very simple bunodont morphology with the crests very lightly developed or even absent (mesoloph and entoloph, or mesolophid and ectolophid are often absent). Because of their simple morphology and their smaller size, and as no other smaller teeth with molar type morphology have been found, these teeth can be unambiguously interpreted as deciduous molars. Thus, we can observe that the shape of the DP4 is more trapezoidal than that of the P4, its labial border being longer than the lingual one. The dp4 has a more elongated shape compared to that of $\mathrm{p} 4$.

\section{Mandible}

Some quite well-preserved mandibles of the smaller-sized eomyid come from Möhren 13 and 20 (unfortunately without complete condyloid and angular processes and without teeth); being edentated they show the radiculation typical for most eomyids: $\mathrm{p} 4$ with 2 roots and molars with two anterior and one posterior root. They allow a direct comparison with the morphology of the type mandible of E. antiquus (Fig. 4). Several features can be observed:

- the mandible is long and slender; the diastema is long and faintly curved;

- the ascending coronoid ramus is in a more forward position, completely hiding the $\mathrm{m} 3$ and a part of the $\mathrm{m} 2$ in lateral view;

- the masseter insertion is V-shaped but weakly marked for the dorsal masseter and the ventral masseter insertions compared to the medial masseter insertion.

- the masseter ends very high up on the mandible under the $\mathrm{p} 4$, close to the mental foramen;

- the mental foramen is very high up on the German material and located in the middle of the diastema, between incisor and p4, as seen in Adjidaumo minimus (Matthew, 1903) (Black 1965: fig. 29; Fahlbusch 1973). However on the type mandible of $E$. antiquus, it is located lower 
down than this. This morphological feature appears to be different, but the lack of material does not allow us to describe any variability on mandibles. Engesser (1990: fig. 29) suggested that this feature could have a strong variability in E. zitteli Schlosser, 1884 (perhaps due to age), therefore we don't interpret this observation as diagnostic. Unfortunately, no mandible from the Oligocene of Asia was described for further morphological comparisons.

Generally speaking, it is noteworthy that features described above for the mandibles from France and Germany are not very different from the mandible of the North American Adjidaumo minimus figured by Black (1965).

\section{CONCLUSION ON THE EOMYS ANTIQUUS}

GERMAN MATERIAL

Among the three eomyids found in Southern Germany, the species described above is the smallest (Fig. 3). The general morphology observed fits with the bunodont tooth-morphology of Eomys antiquus originally described from Ronzon (two lower teeth, $\mathrm{m} 1: 0.85 \times 0,85 \mathrm{~mm} ; \mathrm{m} 2$ : $0.96 \times 0.95 \mathrm{~mm})$. The numerous teeth yielded by these German localities (mainly Möhren 13 and 20) now indicate a noticeable variability in size and morphology for this species, in which the type material of Ronzon is included (Appendix Figs A1-A6 for morphological variability; Fig. 3 for teeth size).

Even though the species Eomys antiquus from Ronzon (the type locality) is poorly documented as the diagnosis was made on a single mandible (Aymard 1853), the direct comparison of the lower molars of Möhren 13 and 20 showed no noticeable differences in morphology or size with the type. Based on tooth morphology, mandible morphology and size, the material from Möhren 13, 20, 19 and Ronheim has been attributed to the species Eomys antiquus.

Based on present knowledge no significant morphological differences can be observed at the beginning of the Oligocene, thus suggesting a large spatial distribution of this species in Europe at the beginning of the Oligocene (biochronological units MP 21 and MP 22).

\section{Eomys aff. E. antiquus (Aymard, 1853)}

(Fig. 5A-Q)

Localities. - French and Spanish localities: SaintMartin-de-Castillon C and F (France); Montalban (Spain).

TeETh Size. - At a first approach of the material, species can be differentiated on size. We first describe the species characterized by small sized teeth found in Saint-Martin-de-Castillon C, F and Montalban, the size of which also corresponds to that of the smaller sized German species. Measurements for Saint-Martin-deCastillon levels and Montalban are given in Tables 4-6 and Figure 7 . This species is clearly differentiated by its size compared to the very small sized species found in La Blache and the medium-sized species found in SaintMartin-de-Castillon J and E.

\section{DESCRIPTION P4}

The general morphology is similar to that of the German material, but some differences can be observed on the labial anteroloph development. The labial anteroloph is generally absent or weakly developed, more rarely well developed. The lingual anteroloph is not clearly developed, usually limited to a weak fold of the enamel suggesting the formation of a crest.

The mesoloph has a noticeable variability, it can be absent, weak or short. When short, the mesoloph can be perpendicular to the axis of the tooth or oblique to the front of the tooth. Three teeth in Saint-Martinde-Castillon present a discontinuous mesoloph. The rest of the teeth have the same type of morphological variability as in the German material.

The entoloph is usually continuous, but can sometimes be broken between the mesoloph and the protocone or between the mesoloph and the hypocone.

\section{M1/2}

On the anterior part of the tooth the labial anteroloph is long, starting at the base of the protoloph. Few teeth have a lingual anteroloph, but when present it can be either weakly or clearly developed. Some rare teeth can have the two anterolophs disconnected from the protoloph. The mesoloph is generally short and curved backward, but on some teeth it can be oblique to the front of the tooth. The mesoloph can also be weak, absent, or long and interrupted in some rare cases at Saint-Martin-de-Castillon. 
TABLE 4. - Measurements (in $\mathrm{mm}$ ) of the population of Eomys aff. E. antiquus (Aymard, 1853) from Saint-Martin-de-Castillon C. Abbreviations: N, number of teeth; Min, minimal value; Max, maximal value; Mean, mean value; SD, standard deviation; CV, coefficient of variation.

\begin{tabular}{|c|c|c|c|c|c|c|c|c|c|c|c|c|}
\hline & \multicolumn{6}{|c|}{ Length } & \multicolumn{6}{|c|}{ Width } \\
\hline & $\mathbf{N}$ & Min & Max & Mean & SD & CV & $\mathbf{N}$ & Min & Max & Mean & SD & CV \\
\hline$\overline{\mathrm{D} 4}$ & 69 & 0.64 & 1.02 & 0.81 & 0.071 & 8.85 & 69 & 0.54 & 0.89 & 0.74 & 0.101 & 13.56 \\
\hline P4 & 84 & 0.74 & 0.96 & 0.86 & 0.050 & 5.80 & 84 & 0.80 & 1.02 & 0.92 & 0.049 & 5.31 \\
\hline $\mathrm{M} 1 / 2$ & 278 & 0.79 & 1.03 & 0.91 & 0.050 & 5.57 & 278 & 0.85 & 1.14 & 0.98 & 0.052 & 5.27 \\
\hline M3 & 87 & 0.59 & 0.82 & 0.70 & 0.042 & 5.99 & 87 & 0.66 & 0.90 & 0.79 & 0.046 & 5.82 \\
\hline $\mathrm{d} 4$ & 52 & 0.81 & 1.02 & 0.89 & 0.048 & 5.36 & 52 & 0.54 & 0.70 & 0.61 & 0.033 & 5.42 \\
\hline $\mathrm{p} 4$ & 68 & 0.75 & 1.02 & 0.90 & 0.049 & 5.45 & 68 & 0.65 & 0.93 & 0.77 & 0.050 & 6.56 \\
\hline $\mathrm{m} 1 / 2$ & 208 & 0.81 & 1.13 & 0.97 & 0.054 & 5.57 & 208 & 0.71 & 1.06 & 0.88 & 0.050 & 5.66 \\
\hline m3 & 102 & 0.73 & 0.98 & 0.88 & 0.050 & 5.69 & 102 & 0.73 & 0.91 & 0.82 & 0.043 & 5.22 \\
\hline
\end{tabular}

TABLE 5. - Measurements (in mm) of the population of Eomys aff. E. antiquus (Aymard, 1853) from Saint-Martin-de-Castillon $\mathrm{F}$. Abbreviations: N, number of teeth; Min, minimal value; Max, maximal value; Mean, mean value; SD, standard deviation; CV, coefficient of variation.

\begin{tabular}{|c|c|c|c|c|c|c|c|c|c|c|c|c|}
\hline & \multicolumn{6}{|c|}{ Length } & \multicolumn{6}{|c|}{ Width } \\
\hline & $\mathbf{N}$ & Min & Max & Mean & SD & CV & $\mathbf{N}$ & Min & Max & Mean & SD & CV \\
\hline D4 & 7 & 0.79 & 0.90 & 0.84 & 0.048 & 5.73 & 7 & 0.78 & 0.87 & 0.84 & 0.037 & 4.37 \\
\hline P4 & 6 & 0.87 & 0.93 & 0.90 & 0.023 & 2.53 & 6 & 0.93 & 0.99 & 0.96 & 0.026 & 2.74 \\
\hline M1/2 & 17 & 0.82 & 1.00 & 0.92 & 0.054 & 5.85 & 17 & 0.89 & 1.15 & 1.00 & 0.080 & 7.93 \\
\hline M3 & 3 & 0.63 & 0.76 & 0.70 & 0.066 & 9.42 & 3 & 0.74 & 0.89 & 0.82 & 0.075 & 9.10 \\
\hline $\mathrm{d} 4$ & 4 & 0.86 & 0.92 & 0.89 & 0.028 & 3.13 & 4 & 0.59 & 0.65 & 0.61 & 0.029 & 4.73 \\
\hline p4 & 4 & 0.88 & 0.96 & 0.92 & 0.033 & 3.56 & 4 & 0.73 & 0.89 & 0.80 & 0.066 & 8.26 \\
\hline $\mathrm{m} 1 / 2$ & 13 & 0.94 & 1.13 & 1.03 & 0.059 & 5.77 & 13 & 0.81 & 1.01 & 0.91 & 0.050 & 5.55 \\
\hline $\mathrm{m} 3$ & 7 & 0.82 & 0.97 & 0.90 & 0.046 & 5.05 & 7 & 0.78 & 0.93 & 0.84 & 0.052 & 6.17 \\
\hline
\end{tabular}

TABLE 6. - Measurements (in mm) of the population of Eomys aff. E. antiquus (Aymard, 1853) from Montalban. Abbreviations: N, number of teeth; Min, minimal value; Max, maximal value; Mean, mean value; SD, standard deviation; CV, coefficient of variation.

\begin{tabular}{|c|c|c|c|c|c|c|c|c|c|c|c|c|}
\hline & \multicolumn{6}{|c|}{ Length } & \multicolumn{6}{|c|}{ Width } \\
\hline & $\mathbf{N}$ & Min & Max & Mean & SD & CV & $\mathbf{N}$ & Min & Max & Mean & SD & CV \\
\hline D4 & 2 & 0.73 & 0.80 & 0.76 & - & - & 2 & 0.82 & 0.84 & 0.83 & - & - \\
\hline P4 & 5 & 0.75 & 0.89 & 0.82 & 0.051 & 6.26 & 5 & 0.80 & 0.96 & 0.88 & 0.058 & 6.67 \\
\hline $\mathrm{M} 1 / 2$ & 8 & 0.82 & 0.89 & 0.86 & 0.028 & 3.23 & 8 & 0.93 & 1.04 & 0.98 & 0.050 & 5.08 \\
\hline M3 & 2 & 0.65 & 0.69 & 0.67 & - & - & 2 & 0.78 & 0.86 & 0.82 & - & - \\
\hline $\mathrm{d} 4$ & 1 & - & - & 0.98 & - & - & 1 & - & - & 0.61 & - & - \\
\hline p4 & 3 & 0.84 & 0.87 & 0.86 & 0.017 & 1.95 & 3 & 0.70 & 0.83 & 0.76 & 0.064 & 8.40 \\
\hline $\mathrm{m} 1 / 2$ & 6 & 0.90 & 1.06 & 0.96 & 0.060 & 6.26 & 6 & 0.84 & 0.92 & 0.88 & 0.036 & 4.07 \\
\hline $\mathrm{m} 3$ & 2 & 0.83 & 0.85 & 0.84 & - & - & 2 & 0.81 & 0.81 & 0.81 & - & - \\
\hline
\end{tabular}

Some teeth clearly present two mesolophs (Appendix Fig. A2-I).

As for the P4, the entoloph is usually continuous, but can sometimes be broken between the mesoloph and the protocone or between the mesoloph and the hypocone, or even both at the same time, leading to an isolated mesoloph (Appendix Fig. A2-Rare morphologies). One tooth in Saint-Martin-de-Castillon has a paracone disconnected from the entoloph (Appendix Fig. A2-Rare morphologies). 

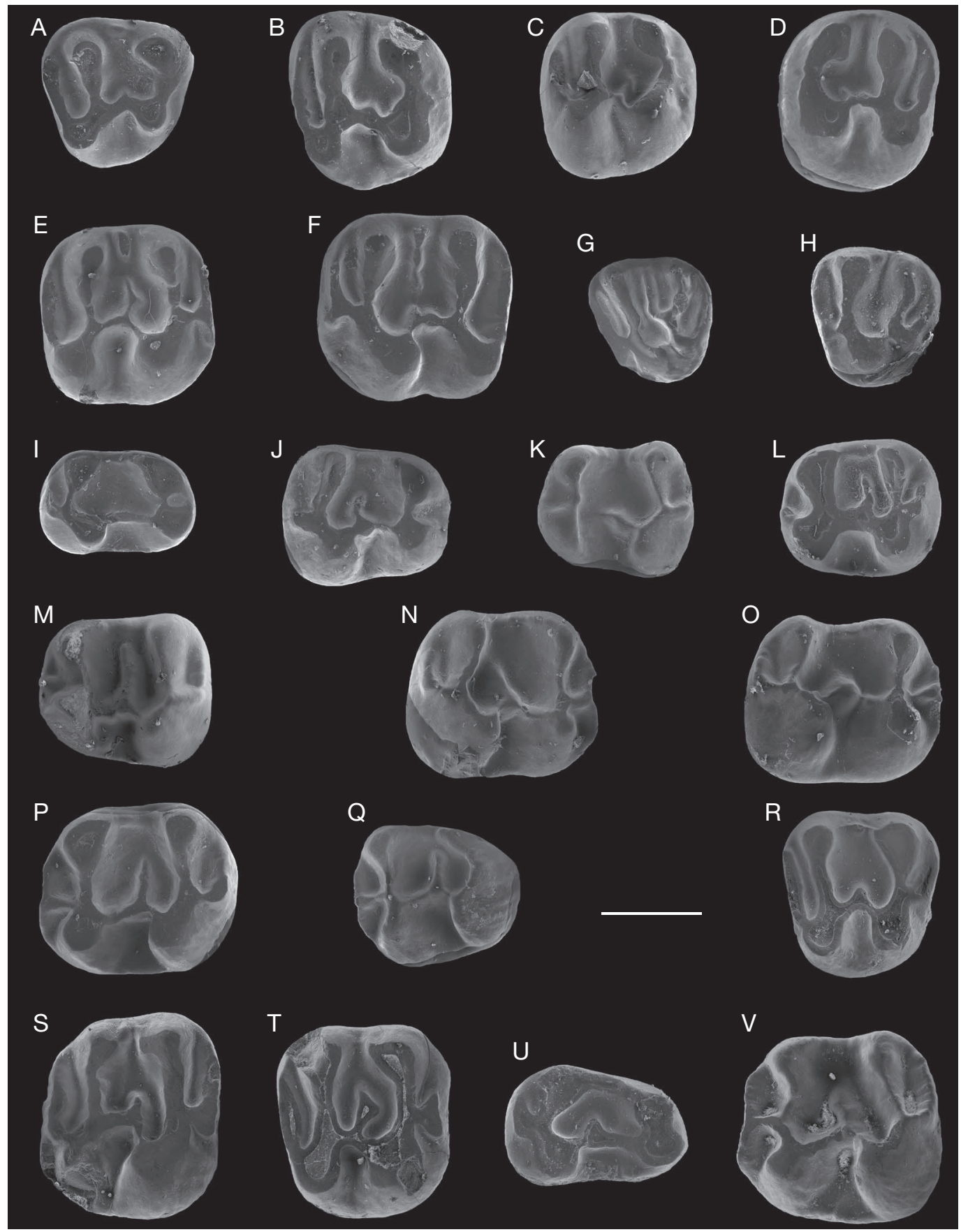

FIG. 5. - A-Q, Eomys aff. E. antiquus (Aymard, 1853) teeth, Saint-Martin-de-Castillon C; A, RDP4, FSL 98150; B, RP4, FSL 98155; C, RP4, FSL 98157; D, LP4, FSL 98162; E, RM1/2, FSL 98164; F, LM1/2, FSL 98160; G, LM3, FSL 98153; H, LM3, FSL 98169; I, Rdp4, FSL 98167; J, Rp4, FSL 98166; K, Lp4, FSL 98159; L, Lp4, FSL 98154; M, Lp4, FSL 98158; N, Rm1/2, FSL 98151; O, Rm1/2, FSL 98156; P, Lm1/2, FSL 98163; Q, Lm3, FSL 98161; R-V, Eomys aff. E. zitteli Schlosser, 1884 teeth, Saint-Martin-de-Castillon J; R, RDP4, FSL 98180; S, RM1/2, FSL 98178; T, RM1/2, FSL 98179; U, Rdp4, FSL 98176; V, Lm1/2, FSL 98177. Scale bar: 0.5 mm. 
M3

The general shape of the tooth is triangular rounded, its posterior part is generally larger than in the German material. The anterior part of the tooth has little morphological variability. The labial anteroloph is always long, starting from the base of the paraloph. A short and weaklydeveloped lingual anteroloph can be observed on some teeth.

The morphology generally has a higher variability on the posterior part around the metaloph. The metaloph is usually completely developed, reaching the labial border, but it can also be short or absent.

A forward crest (mesoloph) can start from the metaloph. It can be short or reaching the labial border of the tooth, and in some rare cases connected to the protoloph (Appendix Fig. A3-Rare morphologies). A backward crest can also appear, linking the metaloph and the posteroloph.

\section{$p 4$}

The general morphology is similar to that of the material from the German localities but some slight differences can be observed in the variability. The anterior part is always divided into two conids. Most of the time they are linked by a transverse crest, but they can also be almost joining each other or both linked backward on the ectolophid, but are never clearly separated. An anteroconid, connected to the protoconid, can sometimes be observed and for one tooth this cusp takes the shape of a real anterolophid (one case observed in Montalban).

The mesolophid is generally short but with a noticeable variability, it can be absent, weak or reaching the lingual border. In some rare cases, the mesolophid can be directly connected to the metaconid by a fore-spur (one case observed in Saint-Martin-de-Castillon C). In the posterior part, the posterolophid is often weakly developed, closely positioned to the hypolophid, delimiting a narrow posterosinus, but it can also be well developed. Some teeth do not show a posterolophid. The ectolophid is generally continuous but some teeth have a disconnection between the protoconid and the mesolophid (Fig. 5K). $m 1 / 2$

In the anterior part of the tooth, the labial and lingual anterolophids are generally both well developed, but the labial one can sometimes be shorter or even absent. When the labial anterolophid is strongly developed, the sinus between it and the protoconid can be very wide leading to a round shape of the anterolophid that is clearly observable in the tooth outline. The protoconid is generally oriented forward (Fig. 5N-P).

The anterolophids are usually connected to the protoconid but the connection can sometimes be more lingual, being connected to the metalophid, and sometimes disconnected, leading to an isolated anterior crest. The mesolophid has little variability, generally of average size, very rarely weak (Fig. 5O) or absent. The ectolophid can sometimes be interrupted leading to an isolated mesolophid in the middle of the tooth. The posterolophid is always present even if sometimes reduced to a spur.

$m 3$

As for the $\mathrm{m} 1 / 2$, the labial and lingual anterolophids are generally both well developed with some variability in their connection that can be with the protoconid or with the metalophid. The anterolophids can also very often be disconnected, leading so to an isolated fore-crest.

The mesolophid is always well developed, of medium size or long, reaching the lingual side of the tooth in most cases. The ectolophid is usually continuous, but it can be broken between the mesolophid and the hypoconid.

The entoconid is generally weakly developed, matching the thickness of the posterior crest on its lingual part, but rarely absent.

On some rare teeth, a longitudinal spur can appear between the posterolophid and the mesolophid, starting from the mesolophid or from the posterolophid. This spur can be weakly developed or well-developed linking the mesolophid and the posterolophid (Appendix Fig. A6-IV).

\section{DP4 and $d p 4$}

Some teeth have been found in the French and Spanish localities that have the same morphology as in Möhren 13 and 20. 
TABLE 7. - Comparison of the teeth size of Eomys antiquus (Aymard, 1853) from Germany and E. aff. E. antiquus from France and Spain with the non-parametric test of Mann-Whitney. The test was run on the length and the width of teeth. The significance $(\boldsymbol{P})$ and the number of specimens $(\mathbf{N})$ is given for each couple of localities. When significant $(<0.01)$ or highly significant $(<0.001)$, the results are indicated in bold characters.

\begin{tabular}{|c|c|c|c|c|c|}
\hline & $\begin{array}{l}\text { Möhren } 13 \\
\text { vs Möhren } 20\end{array}$ & $\begin{array}{l}\text { Montalban } \\
\text { vs Möhren } 13\end{array}$ & $\begin{array}{l}\text { Montalban vs } \\
\text { Saint-Martin C }\end{array}$ & $\begin{array}{l}\text { Saint-Martin C } \\
\text { vs Möhren } 13\end{array}$ & $\begin{array}{l}\text { Saint-Martin C } \\
\text { vs Saint-Martin F }\end{array}$ \\
\hline \multicolumn{6}{|l|}{ P4 } \\
\hline \multirow[t]{2}{*}{ Length } & $P=0.718$ & $P=0.257$ & $P=0.083$ & $P<0.001$ & $P=0.027$ \\
\hline & $\mathrm{N}: 47 \mathrm{~N}: 7$ & $\mathrm{~N}: 5 \mathrm{~N}: 47$ & $\mathrm{~N}: 5 \mathrm{~N}: 84$ & N:84 N:47 & $\mathrm{N}: 84 \mathrm{~N}: 6$ \\
\hline \multirow[t]{2}{*}{ Width } & $P=0.470$ & $P=0.034$ & $P=0.127$ & $P<0.001$ & $P=0.019$ \\
\hline & $\mathrm{N}: 47 \mathrm{~N}: 7$ & $\mathrm{~N}: 5 \mathrm{~N}: 47$ & $\mathrm{~N}: 5 \mathrm{~N}: 84$ & $\mathrm{~N}: 84 \mathrm{~N}: 47$ & $\mathrm{~N}: 84 \mathrm{~N}: 6$ \\
\hline \multicolumn{6}{|l|}{ M1/2 } \\
\hline \multirow[t]{2}{*}{ Length } & $P=0.329$ & $P<0.001$ & $P=0.005$ & $P=0.583$ & $P=0.541$ \\
\hline & $\mathrm{N}: 85 \mathrm{~N}: 12$ & $\mathrm{~N}: 8 \mathrm{~N}: 85$ & N:8 N:283 & $\mathrm{N}: 283 \mathrm{~N}: 85$ & $\mathrm{~N}: 283 \mathrm{~N}: 17$ \\
\hline \multirow[t]{2}{*}{ Width } & $P=0.445$ & $P=0.465$ & $P=0.754$ & $P=0.503$ & $P=0.333$ \\
\hline & $\mathrm{N}: 87 \mathrm{~N}: 13$ & $\mathrm{~N}: 8 \mathrm{~N}: 87$ & $\mathrm{~N}: 8 \mathrm{~N}: 283$ & $\mathrm{~N}: 283 \mathrm{~N}: 87$ & $\mathrm{~N}: 283 \mathrm{~N}: 17$ \\
\hline \multicolumn{6}{|l|}{ M3 } \\
\hline \multirow[t]{2}{*}{ Length } & $P=0.623$ & $P=0.548$ & $P=0.286$ & $P=0.391$ & $P=0.710$ \\
\hline & $\mathrm{N}: 21 \mathrm{~N}: 2$ & $\mathrm{~N}: 2 \mathrm{~N}: 21$ & $\mathrm{~N}: 2 \mathrm{~N}: 87$ & $\mathrm{~N}: 87 \mathrm{~N}: 21$ & $\mathrm{~N}: 87 \mathrm{~N}: 3$ \\
\hline \multirow[t]{2}{*}{ Width } & $P=0.209$ & $P=0.870$ & $P=0.332$ & $P<0.001$ & $P=0.399$ \\
\hline & $\mathrm{N}: 21 \mathrm{~N}: 2$ & $\mathrm{~N}: 2 \mathrm{~N}: 21$ & $\mathrm{~N}: 2 \mathrm{~N}: 87$ & N:87 N:21 & $\mathrm{N}: 87 \mathrm{~N}: 3$ \\
\hline \multicolumn{6}{|l|}{ p4 } \\
\hline \multirow[t]{2}{*}{ Length } & $P=0.147$ & $P=0.067$ & $P=0.045$ & $P<0.001$ & $P=0.337$ \\
\hline & $\mathrm{N}: 45 \mathrm{~N}: 7$ & $\mathrm{~N}: 3 \mathrm{~N}: 45$ & $N: 3 N: 68$ & N:68 N:45 & $\mathrm{N}: 68 \mathrm{~N}: 4$ \\
\hline \multirow[t]{2}{*}{ Width } & $P=0.823$ & $P=0.573$ & $P=0.720$ & $P<0.001$ & $P=0.253$ \\
\hline & $\mathrm{N}: 46 \mathrm{~N}: 7$ & $N: 3 N: 46$ & $\mathrm{~N}: 3 \mathrm{~N}: 68$ & $\mathrm{~N}: 68 \mathrm{~N}: 46$ & $\mathrm{~N}: 68 \mathrm{~N}: 4$ \\
\hline \multicolumn{6}{|l|}{$\mathrm{m} 1 / 2$} \\
\hline \multirow{2}{*}{ Length } & $P=0.152$ & $P=0.462$ & $P=0.531$ & $P=0.826$ & $P=0.001$ \\
\hline & $\mathrm{N}: 61 \mathrm{~N}: 16$ & $\mathrm{~N}: 6 \mathrm{~N}: 61$ & N:6 N:208 & N:208 N:61 & N:208 N:13 \\
\hline \multirow[t]{2}{*}{ Width } & $P=0.480$ & $P=0.015$ & $P=0.989$ & $P<0.001$ & $P=0.049$ \\
\hline & $\mathrm{N}: 62 \mathrm{~N}: 16$ & $\mathrm{~N}: 6 \mathrm{~N}: 62$ & N:6 N:208 & N:208 N:62 & $\mathrm{N}: 208 \mathrm{~N}: 13$ \\
\hline \multicolumn{6}{|l|}{ m3 } \\
\hline \multirow[t]{2}{*}{ Length } & $P=0.631$ & $P=0.126$ & $P=0.166$ & $P=0.921$ & $P=0.183$ \\
\hline & $\mathrm{N}: 53 \mathrm{~N}: 10$ & $\mathrm{~N}: 2 \mathrm{~N}: 53$ & $\mathrm{~N}: 2 \mathrm{~N}: 102$ & $\mathrm{~N}: 102 \mathrm{~N}: 53$ & $\mathrm{~N}: 102 \mathrm{~N}: 7$ \\
\hline \multirow[t]{2}{*}{ Width } & $P=0.116$ & $P=0.982$ & $P=0.785$ & $P=0.868$ & $P=0.344$ \\
\hline & $\mathrm{N}: 53 \mathrm{~N}: 10$ & $\mathrm{~N}: 2 \mathrm{~N}: 53$ & $\mathrm{~N}: 2 \mathrm{~N}: 102$ & $\mathrm{~N}: 102 \mathrm{~N}: 53$ & $\mathrm{~N}: 102 \mathrm{~N}: 7$ \\
\hline
\end{tabular}

CONCLUSION ON THE EOMYS AFF. E. ANTIQUUS FRENCH AND SPANISH MATERIAL

For Saint-Martin-de-Castillon C and F eomyids seem to belong to a single population not very different of that of the slightly older locality at Montalban. Considering that morphological variability beyond the type specimen (from Ronzon MP 21) is unknown, the specimens from Montalban (MP 23) and SaintMartin-de-Castillon (MP 24) are here mainly compared with the specimens from Germany (Möhren 13 and 20, MP 21). Some significant morphological differences can be observed, such as:

- an isolated labial anteroloph in P4 in Germany (not in France or Spain), the labial anteroloph of P4 is less developed on French and Spanish material and the mesoloph more frequently developed on French material (Appendix Fig. A1-III);

- on M1-2, 3-6\% of the French teeth show a long interrupted mesoloph that is never seen on German and Spanish material (Appendix Fig. A2-I);

- the absence of metaloph in M3 in Germany (not in France or Spain); the metaloph and the mesoloph of M3 are more developed on French specimens (Appendix Fig. A3);

- in German material, a clearly divided anteroconid exists on p4, (not in France or Spain) the connection between the metaconid and the protoconid is rare whereas it is more common in French and Spanish material and the mesolophid seems shorter in German localities (Appendix Fig. A4); 
- long mesolophids never exist on m1-2 (Appendix Fig. A5);

- the mesolophid is more developed on $\mathrm{m} 3$ in French and Spanish specimens (Appendix Fig. A6).

Concerning the size of teeth (Fig. 7), a comparison between these localities has been made using the Mann-Whitney test. This non-parametric test has been chosen because the discrepancy in the number of specimens between the localities does not allow us to check if the values in each sample are normally distributed. The results (see Table 7) confirm the size similarity between Möhren 20 and 13, but also the close size relationship between Saint-Martin-deCastillon $\mathrm{C}$ and F. However a significant difference is observed on the length of the $\mathrm{m} 1 / 2$ between the two levels of Saint-Martin-de-Castillon, the teeth of the upper level, Saint-Martin-de-Castillon F, being larger. Concerning Montalban, the results are more difficult to interpret because of the generally low number of specimens, likely to affect the result of the test. Montalban presents generally few significant differences with both the German and French localities. However the M1/2 seem to be shorter than the specimens from both Germany and France which might indicate a geographical differentiation. For the remaining teeth, the size in Montalban appears to be intermediate between the German and French localities. The comparison of Möhren 13 with Saint-Martin-de-Castillon C (both with an important number of specimens) indicates a clear difference in the size on the premolars (the German ones being significantly smaller) and also in the width of $\mathrm{M} 3$ and $\mathrm{m} 1 / 2$, which is in accordance with the observations made of the morphology. These results indicate a faint size enlargement over time which is not always the case in later eomyids.

Considering that the localities from Southern Germany are probably much older (more or less $3 \mathrm{Ma}$ ) than the French and Spanish localities studied, the differences observed above are likely the result of morphological evolution that more strongly affect the teeth at the extremities of the tooth row. The size and morphology of the type material of $E$. antiquus $(2 \mathrm{ml} / 2$ : $0.85 \times 0,85 \mathrm{~mm} ; 0.96 \times 0.95 \mathrm{~mm})$ are indeed included in the variability described for Montalban and Saint-Martin-de-Castillon C and F. For this reason the populations of the French and Spanish localities are attributed to Eomys aff. E. antiquus.

\section{DISCUSSION}

The general morphology described above for the German, French and Spanish small-sized species is characterized by very brachyodont teeth with a bunodont tooth topology based on four main cusps. The longitudinal crest, rarely interrupted, is more or less lingually-located on upper premolars and molars, and labially-located on lower premolars and molars leading to very long transverse crests (protoloph and metaloph for upper teeth and metalophid and hypolophid for lower teeth) beyond the middle axis of the teeth.

The single mandible found in the type locality does not allow us to address the question of the morphological evolution of $E$. antiquus mandible between MP 21 and MP 24. However the significant number of teeth found in Möhren 13, Möhren 20 and Saint-Martin-de-Castillon (mainly the level C) allows a more precise morphological comparison in order to characterize such a potential evolution. Indeed, the comparisons show, at first, a very similar morphology, but also point out some differences mainly on premolars and third molars, whereas first and second molars are almost identical.

Among the small Eomys forms known from the Early Oligocene, the particular morphologies described from Lovagny (MP 23) by Engesser (1990) can be found in Möhren 13 as well as in Montalban or SaintMartin-de-Castillon C and, in our opinion, the teeth of Lovagny can be included in E. antiquus.

From the Early/late Oligocene transition (MP 25 level), the material of Bumbach 1(MP 25: Engesser 1990) has been compared (on cast) with the German and French material. It appears that the morphological features of $E$. nov. sp. 2 are included in the morphological variability of $E$. antiquus from the new material of Germany. However, the upper teeth seem to show long mesolophs more frequently. Eomys molassicus Engesser, 1987 is a later form (Oensingen, MP 26) characterized by its slightly larger size, its very brachyodont teeth with long mesolophs/mesolophids and well-developed anterolophs/anterolophids. Also a noticeable 
peculiarity of the E. molassicus mandible, besides its high ramus horizontalis, is the very large and a little furrowed enamel band on the labial side of its incisor (Engesser 1987: fig. 5d and cast). In our opinion, based on what we know now on the potential morphological variability of species for the genus Eomys, E. nov. sp. 2 could be either related to $E$. antiquus or to $E$. molassicus.

It is worth noting that in the MP 26 level, two clearly different lineages are present: a very brachyodont one, E. molassicus and another with incipient mesodonty, Eomys zitteli known in Mas-de-Pauffié. Their relationships with $E$. antiquus are not clear at the time.

Eomys minor Comte \& Vianey-Liaud, 1987 (Fig. 6)

TyPe LOCAlity. - Belgarric (Quercy, France).

OTHER STUdied LOCALITY. — La Blache (France).

TEETH SIZE. - Eomys minor was described by Comte \& Vianey-Liaud (1987; error as E. minus) as the smallest eomyid known in the Early Oligocene of Europe. It is indeed a very small species, but it would be actually difficult to separate this species from $E$. antiquus solely based on size.

Belgarric - m1/2: $0.87 \times 0.72 \mathrm{~mm} ; 0.83 \times 0.73 \mathrm{~mm}$. La Blache - M1/2: $0.78 \times 0.80 \mathrm{~mm} ; \mathrm{M} 3: 0.74 \times 0.83 \mathrm{~mm}$; p4: $0.79 \times 0.70 \mathrm{~mm} ; \mathrm{m} 1 / 2: 0.88 \times 0.89 \mathrm{~mm}$; $0.91 \times 0.80 \mathrm{~mm}$.

\section{DESCRIPTION}

The teeth are brachyodont but the tubercles seem to be proportionally high.

\section{$M 1 / 2$}

The rather worn tooth presents a very simple morphology, with massive cusps fused into two transverse and separated crests, no entoloph and no mesoloph. The protocone is directed obliquely backward.

\section{M3}

As for the M1/2 the cusps are massive. There are four transverse crests; the labial anteroloph is long and joins an anterocone. The entoloph is very thin without mesoloph. The posteroloph is long and dis-

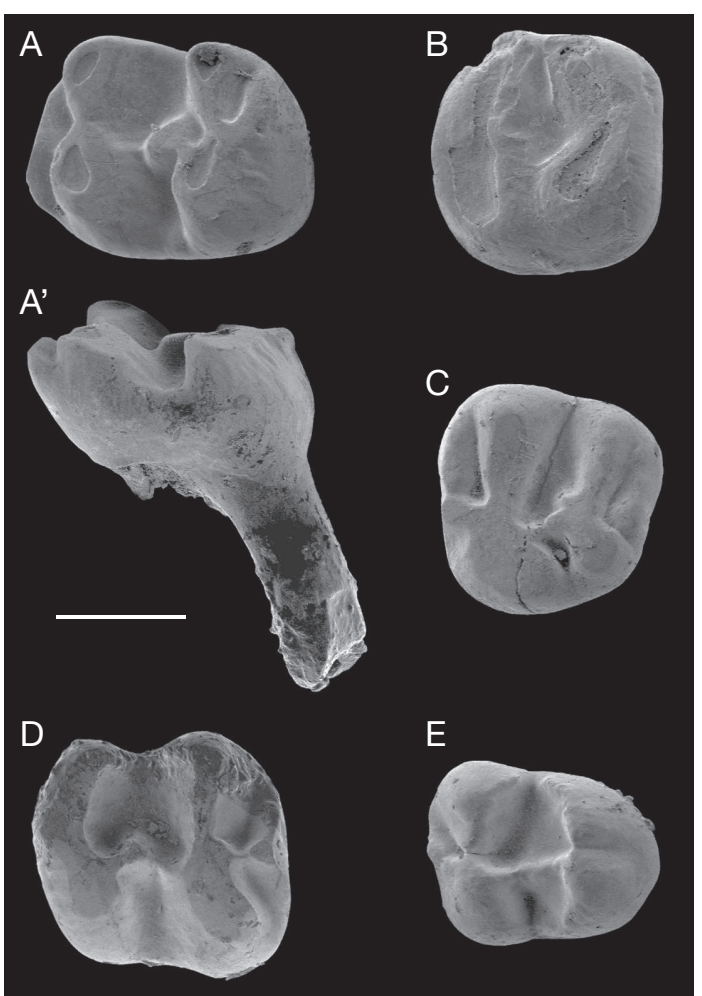

FIG. 6. - Eomys minor Comte \& Vianey-Liaud, 1987 teeth, La Blache: A, A', Lm1/2, FSL 98182; A, occlusal view; A', labial view; B, RM1/2, FSL 98183; C, LM3, FSL 98184; D, Rm1/2, FSL 98185; E, Rp4, FSL 98186 . Scale bar: $0.5 \mathrm{~mm}$.

connected from the hypocone at its base. Protocone and hypocone are directed obliquely backward.

$p 4$

As for the other teeth, the morphology is simple; the low ectolophid is very thin, without mesolophid. The anterior part is clearly divided into two cusps. The posterolophid is weakly developed and represented by a spur on the posterior part of the tooth.

$m 1 / 2$

The two teeth from Belgarric and the two teeth from La Blache have a very similar morphology, with massive cusps and very simple bunodont morphology. The two teeth from Belgarric have no mesolophid and a weakly-developed posterolophid reduced to a spur. One of the two teeth 
TABLE 8. - Measurements (in mm) of the population of Eomys aff. E. zitteli Schlosser, 1884 from Saint-Martin-de-Castillon J. Abbreviations: N, number of teeth; Min, minimal value; Max, maximal value; Mean, Mean value; SD, standard deviation; CV, coefficient of variation.

\begin{tabular}{|c|c|c|c|c|c|c|c|c|c|c|c|c|}
\hline & \multicolumn{6}{|c|}{ Length } & \multicolumn{6}{|c|}{ Width } \\
\hline & $\mathbf{N}$ & Min & Max & Mean & SD & CV & $\mathbf{N}$ & Min & Max & Mean & SD & CV \\
\hline$\overline{\mathrm{D} 4}$ & 10 & 0.71 & 0.94 & 0.82 & 0.071 & 8.62 & 10 & 0.70 & 0.97 & 0.87 & 0.076 & 8.72 \\
\hline P4 & 3 & 0.93 & 0.94 & 0.93 & 0.008 & 0.90 & 3 & 0.91 & 1.03 & 0.97 & 0.059 & 6.04 \\
\hline $\mathrm{M} 1 / 2$ & 17 & 0.88 & 1.07 & 0.97 & 0.055 & 5.73 & 17 & 1.02 & 1.12 & 1.07 & 0.034 & 3.18 \\
\hline M3 & 1 & - & - & 0.83 & - & - & 1 & - & - & 0.93 & - & - \\
\hline $\mathrm{d} 4$ & 12 & 0.83 & 1.02 & 0.96 & 0.053 & 5.50 & 12 & 0.58 & 0.71 & 0.66 & 0.038 & 5.76 \\
\hline p4 & 4 & 0.93 & 1.05 & 0.97 & 0.054 & 5.59 & 4 & 0.83 & 0.87 & 0.85 & 0.017 & 2.02 \\
\hline $\mathrm{m} 1 / 2$ & 16 & 0.93 & 1.16 & 1.07 & 0.065 & 6.01 & 16 & 0.89 & 1.04 & 0.99 & 0.033 & 3.37 \\
\hline $\mathrm{m} 3$ & 6 & 0.84 & 1.01 & 0.93 & 0.055 & 5.91 & 6 & 0.85 & 0.97 & 0.91 & 0.049 & 5.37 \\
\hline
\end{tabular}

TABLE 9. - Measurements (in mm) of the population of Eomys aff. E. zitteli Schlosser, 1884 from Saint-Martin-de-Castillon E. Abbreviations: N, number of teeth; Min, minimal value; Max, maximal value; Mean, Mean value; SD, standard deviation; CV, coefficient of variation.

\begin{tabular}{|c|c|c|c|c|c|c|c|c|c|c|c|c|}
\hline & \multicolumn{6}{|c|}{ Length } & \multicolumn{6}{|c|}{ Width } \\
\hline & $\mathbf{N}$ & Min & Max & Mean & SD & CV & $\mathbf{N}$ & Min & Max & Mean & SD & CV \\
\hline$\overline{\mathrm{D} 4}$ & 3 & 0.77 & 0.88 & 0.83 & 0.056 & 6.71 & 3 & 0.87 & 0.93 & 0.91 & 0.035 & 3.81 \\
\hline P4 & 3 & 0.91 & 0.95 & 0.93 & 0.021 & 2.25 & 3 & 0.94 & 1.05 & 0.99 & 0.055 & 5.54 \\
\hline $\mathrm{M} 1 / 2$ & 5 & 0.93 & 0.99 & 0.95 & 0.024 & 2.51 & 5 & 1.04 & 1.13 & 1.07 & 0.035 & 3.27 \\
\hline M3 & 2 & 0.64 & 0.76 & 0.70 & - & - & 2 & 0.83 & 0.89 & 0.86 & - & - \\
\hline $\mathrm{d} 4$ & 3 & 0.92 & 1.00 & 0.96 & 0.040 & 4.17 & 3 & 0.61 & 0.68 & 0.66 & 0.040 & 6.15 \\
\hline p4 & 3 & 0.97 & 1.01 & 0.99 & 0.020 & 2.02 & 3 & 0.84 & 0.92 & 0.88 & 0.040 & 4.61 \\
\hline $\mathrm{m} 1 / 2$ & 8 & 0.99 & 1.12 & 1.05 & 0.047 & 4.45 & 8 & 0.87 & 1.04 & 0.95 & 0.053 & 5.65 \\
\hline m3 & 4 & 0.88 & 0.94 & 0.92 & 0.026 & 2.87 & 4 & 0.87 & 0.90 & 0.89 & 0.013 & 1.46 \\
\hline
\end{tabular}

from La Blache has exactly the same morphology whereas the other one is slightly different with no ectolophid and a short spur connected to the hypoconid that could be interpreted as a very weakly-developed mesoconid. On this tooth, the posterolophid is short but clearly more developed than a spur and the anterior root is not completely bifurcated as it is the case for E. antiquus. As in the material from Belgarric, a long anterolophid exists but, as the teeth are unworn, is not connected to the protoconid.

\section{Mandible}

It is noteworthy that a second mandible without teeth found in Belgarric is also clearly different from the mandibles of $E$. antiquus from Möhren 13, 20 and Ronzon. The diastema is flat, almost not curved, the ascending coronoid ramus is weakly slant, hiding only the third molar and all the masseter insertions are weakly marked.

\section{DISCUSSION}

The size of this species seems to be smaller than $E$. antiquus but teeth are close to the smallest E. antiquus teeth. The measurements, taken directly on the type material (USTL BEL 470) for this study, indicated that part of the values given by Comte \& Vianey-Liaud (1987) were underestimated and that the width of the teeth is not clearly smaller than for E. antiquus of Southern Germany (E. minor, $\mathrm{m} 1: 0.87 \times 0.72 \mathrm{~mm}, \mathrm{~m} 2: 0.83 \times 0.73$ $\mathrm{mm}$; E. antiquus Ronzon, $\mathrm{m} 1: 0.85 \times 0.85 \mathrm{~mm}$, $\mathrm{m} 2: 0.96 \times 0.95 \mathrm{~mm}$ ). However the diagnosis is still valid as the morphology of $E$. minor can easily be differentiated from that of E. antiquus: the longitudinal crest, often interrupted and centrallylocated on both upper and lower teeth leading to short connections between the cusps; the latter also present a massive morphology, the mesoloph(id)s are absent and the posterolophid is generally short or reduced to a posterior spur. 
Based on these features, the teeth from La Blache can undoubtedly be attributed to E. minor and the fact that, in this locality, only this species is present confirms that $E$. minor is a valid species and not simply the smallest individuals of an E. antiquus population.

In the locality Bumbach1, Engesser (1990) also described a minute P4 $(0.58 \times 0.64 \mathrm{~mm}$; but a little corroded) as Eomys nov. sp. 3. A single tooth is difficult to assign; it seems unlikely that it could be a P3, such teeth being known in the late Eocene Symplokeomys Emry, Wang, Tjutkova \& Lucas, 1997 but it is of interest to notice that the age of Bumbach 1 is equivalent to the Quercy level Belgarric (MP 25) where Comte \& VianeyLiaud (1987) described Eomys minor. A further comparison of the material would probably decide if Eomys nov. sp. 3 from Bumbach1 can be related to E. minor. Anyhow the presence of E. minor in at least two localities supports the assumption that $E$. minor represents an independent lineage as early as the MP 24/25 Oligocene.

\section{Eomys aff. E. zitteli Schlosser, 1884}

(Fig. 5R-V)

NeOTYPE. - Right mandible with p4-m3, QT 928, NMB; designated by Fahlbusch (1970: 104).

TYPE LOCALITY. - Quercy (old collections; France).

Other STUdied LOCALITIES. — Saint-Martin-de-Castillon $\mathrm{J}$ and $\mathrm{E}$ (France).

TEETH SIZE. - The teeth from Saint-Martin-de-Castillon $\mathrm{E}$ and J can be first separated from the teeth from SaintMartin-de-Castillon C and F, based on their larger size. Also a detailed study points out to clear morphological differences.

Neotype of Eomys zitteli (mandible) - p4: $1.10 \times 0.97 \mathrm{~mm}$; $\mathrm{m} 1 / 2: 1.15 \times 1.11 \mathrm{~mm} ; 1.13 \times 1.15 \mathrm{~mm} ; \mathrm{m} 3$ : $1.00 \times 0.98 \mathrm{~mm}$.

Measurements for the specimens from Saint-Martin-deCastillon levels are given in Tables 8; 9 and Figure 7.

\section{DESCRIPTION}

\section{DP4 and P4}

Its anteroloph is frequently double, the lingual part being developed, which is rarely the case in other
Eomys species; double anterolophs are also frequent on E. zitteli P4 from Mas-de-Pauffié, DP4 being unknown in this locality.

\section{M1/2}

The general morphology is similar to the teeth from the other levels of Saint-Martin-de-Castillon, but some slight differences can be noted with respect to the variation. The mesoloph is always well developed as opposed to the teeth from Saint-Martin-de-Castillon $\mathrm{F}$ and $\mathrm{C}$ where it can be very short or even absent. Some teeth also present a clear division of the mesoloph. The shape of the protocone is often elongated and oblique and the teeth are generally proportionally wider than in Saint-Martin-de-Castillon C and F.

\section{Dp4 and $p 4$}

The shape of the teeth is more elongated in its anterior part than in Saint-Martin-de-Castillon C and F.

\section{$m 1 / 2$}

No significant differences can be observed on the morphological features, but some differences can be observed on the shape, the teeth being proportionally wider. The metalophid is often curved and connected forward on the ectolophid, whereas it is straighter in other levels. In lateral view, no difference can be observed on the height of the crown, but on lingual side the metaconid often presents a bridge merging with median cingulum. This type of morphology is usually absent or weakly marked in Saint-Martinde-Castillon C and F (Fig. 8). In anterior view the cuspids on labial part of the teeth are generally more developed than on the lingual part.

\section{$M 3$ and $m 3$}

Few specimens have been found and no significant differences can be observed either on morphological variability or on tooth shape.

\section{Mandible}

A fragmented mandible found in Saint-Martin-deCastillon E also has a morphology very different from that of Eomys antiquus, with a very deep diastema and a mental foramen located just anterior to $\mathrm{p} 4$ (Fig. 4C). It compares more closely with the mandible of the neotype of E. zitteli (Engesser 1990). 


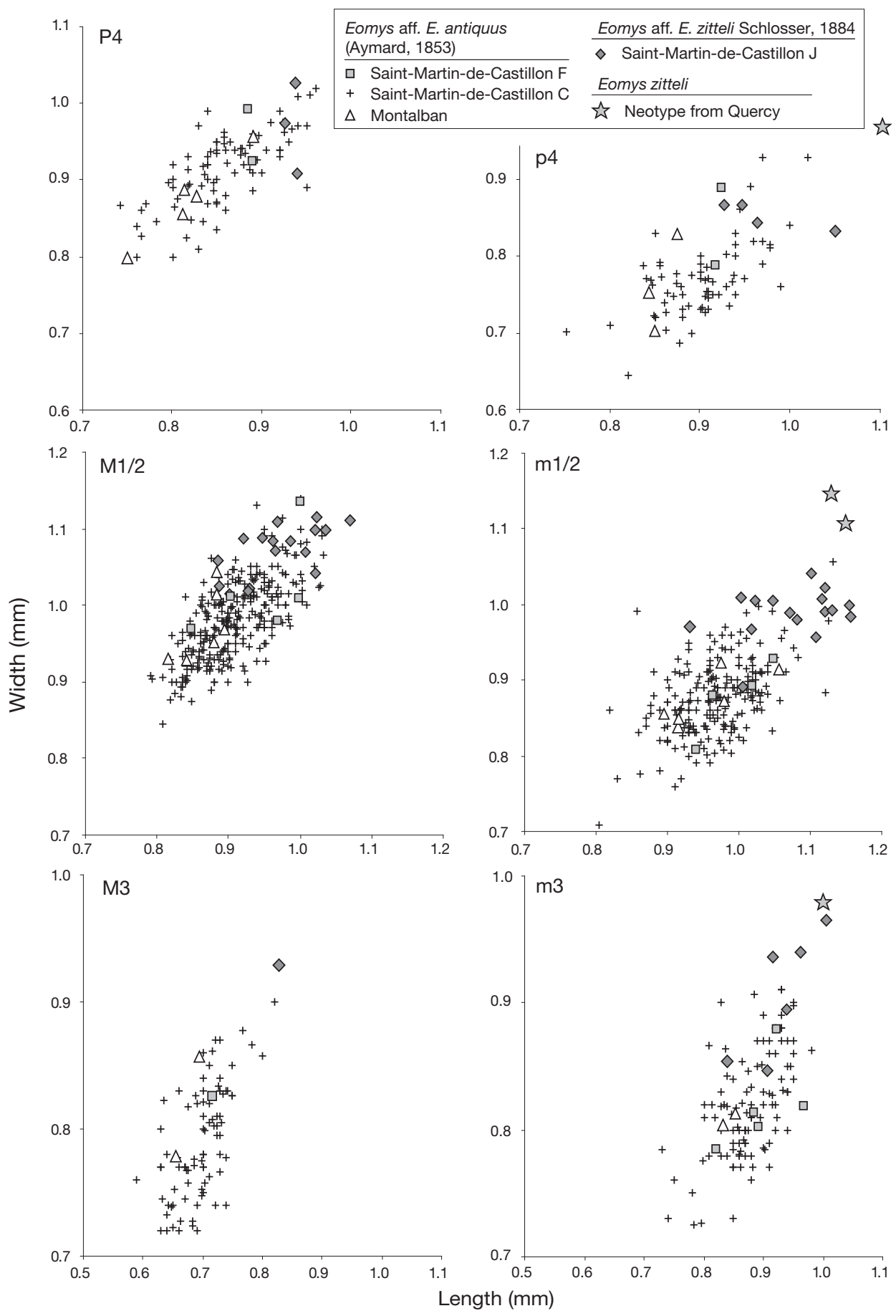

FIG. 7. - Measurements of Eomys Schlosser, 1884 teeth compared between French and Spanish localities The sizes of the teeth from the neotype of $E$. zitteli Schlosser, 1884 are indicated by stars. 
DISCUSSION

The comparison of the material of Eomys from the four different levels of Saint-Martin-de-Castillon provides some morphological differences in the teeth but also some differences in the shape of the mandible (Figs 4; 8).

The eomyids from Saint-Martin-de-Castillon $\mathrm{E}$ and $\mathrm{J}$ are stratigraphically older than those of Saint-Martin-de-Castillon C and F, Saint-Martinde-Castillon $\mathrm{E}$ being situated on the same section as Saint-Martin-de-Castillon C, about $10 \mathrm{~m}$ below.

The size of the teeth from Saint-Martin-de-Castillon $\mathrm{E}$ and $\mathrm{J}$ that is larger than most of the teeth from Saint-Martin C and F and some characteristics (less "squared" teeth, mandible) suggest that $E$. aff. E. antiquus from the younger levels has no relationship with this form. The comparison with the neotype of $E$. zitteli leads to relate the two populations from Saint-Martin-de-Castillon E and J to E. zitteli. However, because these two localities are older than the localities where E. zitteli was hitherto recognized (Mas-de-Pauffié, Quercy, MP 26) and because the size, though equivalent to that of Mas-de-Pauffié (Comte \& Vianey-Liaud 1989) is a little smaller than that of the neotype, we propose E. aff. E. zitteli for Saint-Martin-de-Castillon E and J.

The relationships with the older and larger Eomys sp. from Germany are unclear and the Saint-Martinde-Castillon $\mathrm{E}$ and $\mathrm{J}$ form is likely an immigrant.

\section{Eomys sp. (Fig. 9A-D)}

LOCALITIES. - Möhren 20 and 19 (Germany). Möhren 13 (the two teeth are broken and cannot be measured).

TEETH SIZE. - In German localities a first smaller species of eomyid has been previously described in this study as E. antiquus, but two larger species were also found. We first study the smallest of these two ones.

Möhren 19 - M3: $1.105 \times 1.210 \mathrm{~mm}$.

Measurements for the locality Möhren 20 are given in Table 10

\section{DESCRIPTION}

P4

The tooth is square-shaped, with relatively massive cusps. The paracone is disconnected from the protocone. There is no lingual anteroloph, and
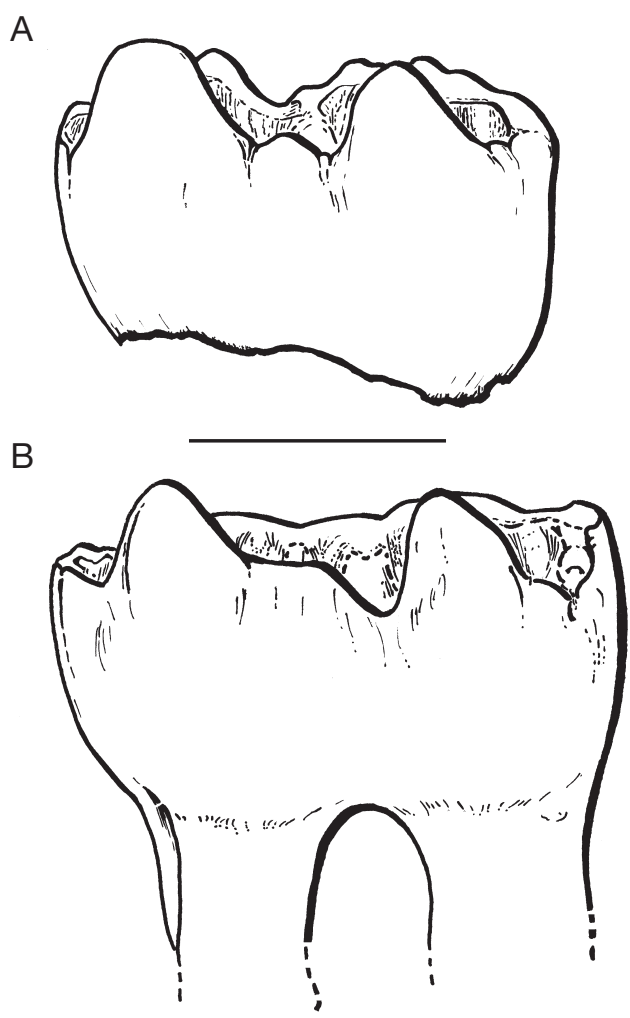

FIG. 8. - Lingual view of $m 1 / 2$ molar from two levels of SaintMartin-de-Castillon: A, Eomys aff. E. antiquus (Aymard, 1853) from the level C (FSL 98156); B, Eomys aff. E. zitteli Schlosser, 1884 from the level J (FSL 98181). Scale bar: $0.5 \mathrm{~mm}$.

the labial one is weakly developed. The mesoloph is short or absent.

\section{$M 1 / 2$}

The teeth have no lingual anteroloph. The labial anteroloph is always long, starting on a protoconule separated from the base of the protoloph. The mesoloph is short, one tooth has a second mesoloph that is oblique and forward-oriented (Fig. 9B).

\section{M3}

The metaloph is in all cases well developed, but opposite to E. antiquus, an accessory crest appears between the basis of the protoloph and the metaloph. The general shape of the teeth is triangular with the posterior part longer than in E. antiquus. 
TABLE 10. - Measurements (in mm) of the population of Eomys sp. from Möhren 20. Abbreviations: N, number of teeth; Min, minimal value; Max, maximal value; Mean, mean value; SD, standard deviation; $\mathbf{C V}$, coefficient of variation.

\begin{tabular}{|c|c|c|c|c|c|c|c|c|c|c|c|c|}
\hline & \multicolumn{6}{|c|}{ Length } & \multicolumn{6}{|c|}{ Width } \\
\hline & $\mathbf{N}$ & Min & Max & Mean & SD & CV & $\mathbf{N}$ & Min & Max & Mean & SD & CV \\
\hline P4 & 2 & 0.95 & 0.97 & 0.96 & - & - & 3 & 0.97 & 1.11 & 1.05 & - & - \\
\hline M1/2 & 5 & 0.98 & 1.09 & 1.02 & 0.046 & 4.51 & 5 & 1.05 & 1.14 & 1.10 & 0.033 & 3.00 \\
\hline M3 & 3 & 0.86 & 1.07 & 0.99 & 0.112 & 11.30 & 3 & 1.10 & 1.14 & 1.12 & 0.018 & 1.61 \\
\hline $\mathrm{m} 1 / 2$ & 6 & 1.16 & 1.31 & 1.21 & 0.054 & 4.46 & 6 & 1.07 & 1.23 & 1.14 & 0.059 & 5.17 \\
\hline
\end{tabular}

TABLE 11. - Measurements (in mm) of the population of Eomyidae gen. et sp. indet. from Möhren 20. Abbreviations: N, number of teeth; Min, minimal value; Max, maximal value; Mean, mean value; SD, standard deviation.

\begin{tabular}{|c|c|c|c|c|c|c|c|c|c|c|c|c|}
\hline & \multicolumn{6}{|c|}{ Length } & \multicolumn{6}{|c|}{ Width } \\
\hline & $\mathbf{N}$ & Min & Max & Mean & SD & CV & $\mathbf{N}$ & Min & Max & Mean & SD & CV \\
\hline P4? & 1 & - & - & 1.16 & - & - & 1 & - & - & 1.19 & - & - \\
\hline $\mathrm{M} 1 / 2$ & 2 & 1.04 & 1.12 & 1.08 & - & - & 3 & 1.14 & 1.21 & 1.18 & - & - \\
\hline
\end{tabular}

$m 1 / 2$

Despite the larger size, the teeth morphology is similar to E. antiquus. The labial and lingual anterolophids are generally both well developed, but the labial one can sometimes be shorter.

When the labial anterolophid is strongly developed, the sinus between it and the protoconid can be very wide, leading to a round shape of the anterolophid that is clearly observable in the tooth outline.

The anterolophids are usually connected to the protoconid, but the connection can sometimes be more lingual and connected to the metalophulid, and sometimes disconnected leading to an isolated forward crest. The mesolophid has little variability, generally of average size.

\section{$m 3$}

The tooth is broken on its forepart. The mesolophid is of medium length and has a posteriorly oriented spur, but does not reach the posterolophid. On the lingual part, the entoconid is reduced to a bump on the posterolophid, but is clearly visible.

\section{DisCUSSION}

These populations can be differentiated from Eomys antiquus from the same localities based mainly on their larger size (Fig. 3; Table 10). The previous description was primarily based on the population found in Möhren 20 where 15 teeth have been found, whereas only two teeth have been found in Möhren 13 and just one in Möhren 19. The morphology of this form is similar to E. antiquus except for the more massive cusps.

The measurements of this population seem to fit with the size of E. molassicus, but one of the diagnostic features of E. molassicus is the presence of long mesolophids whereas they are short on these populations from Möhren 20, 13 and 19. Eomys ebnatensis Engesser, 1987 is also different because of its long mesolophids, larger size and quite mesodont morphology. For these reasons this new material from Bavaria appears to be an original species. It should also be compared with the large teeth from Hoogbutsel described as E. cf. antiquus (Fahlbusch 1973).

The morphology of Eomys sp., with massive cusps and short mesolophids is reminiscent of that of E. major Freudenberg, 1941 from the late Oligocene of Gaimersheim (the type locality) and also Eomys sp. of Treuchtlingen. As the populations of Gaimersheim and Treuchtlingen are larger in size, this population from the Earlier Oligocene could be considered as related to E. major with Eomys sp. from Treuchtlingen as an intermediate form. However the gap in the fossil record between the Early and 


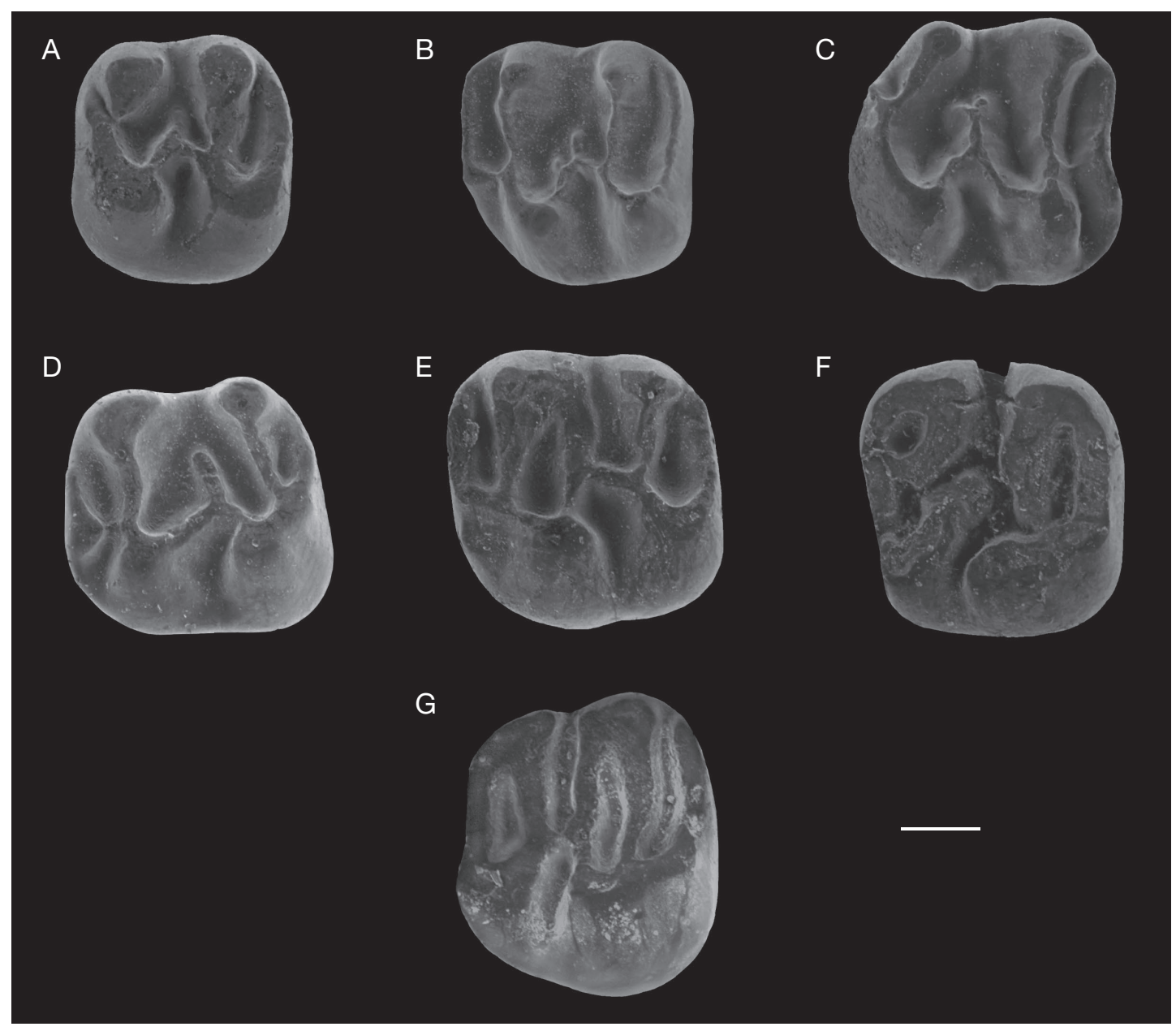

FIG. 9. - A-D, Eomys sp. teeth, Möhren 20; A, LP4, BSP 1975 XXII 837; B, LM1/2, BSP 1975 XXII 846; C, Rm1/2, BSP 1975 XXII 845; D, Lm1/2, BSP 1975 XXII 742; E-G, Eomyidae gen. et sp. indet. teeth, Möhren 20; E, LM1/2, BSP 1975 XXII 858; F, RP4? RM1/2?, BSP 1975 XXII 857; G, RM2, BSP 1975 XXII 853. Scale bar: $0.5 \mathrm{~mm}$.

late Oligocene in Bavaria does not allow to further test this assumption. We therefore propose to leave the nomenclature open, Eomys sp.

Eomyidae gen. et sp. indet. (Fig. 9E-G)

MATERIAL. — Left M1 (BSO 1975 XXII 858), Fig. 9E; right ?P4?M1/2 (BSP 1975 XXII 857), Fig. 9F; right M2 (BSP 1975 XXII 853), Fig. 9G.
LOCALITY. — Möhren 20 (Germany); Early Oligocene (MP 21).

TeEth SIZE. - Measurements are given in Table 11.

\section{DESCRIPTION}

General characteristics: large buno-lophodont Eomyidae with longitudinally elongated paracone and metacone opposed to rounded lingual tubercles; long mesoloph fused with the paracone, entoloph more or less interrupted behind the mesoloph; synclinal I very long on M2. 
Two teeth present a clearly unknown morphology. The large right M2 is clearly wider than long and conspicuously reduced posteriorly. The crests are massive and cusps weakly developed; the difference on cusps development between labial and lingual part is weaker than in other Bavarian eomyids.

Paracone and metacone are stretched longitudinally and the paracone is fused with the labial extremity of the mesoloph. Protocone and hypocone are rounded lingually and hollowed on their labial face. The sinus reaches the middle of the tooth and is slightly oblique antero-labially. The labial anteroloph is very long, starting directly on the anterior arm of the protocone with a right angle, so that syncline I extends over about two thirds of the tooth. Protoloph and mesoloph are roughly parallel and have the same length as anteroloph so that synclines I and II are equal in length. In relationship with the long sinus, syncline III is shorter and opens labially. The metaloph, slightly oblique, joins the anterior arm of the hypocone, which is a little antero-labially orientated. The posteroloph is well developed and, with wear, joins the metacone and the posterior arm of the hypocone and, with further wear, its lingual part. Syncline IV is a little shorter than the anterior synclines. The entoloph is faintly interrupted behind the mesoloph.

The two other teeth display some variations; they are more quadrate with round angles.

- The pattern of the left M1 is very similar to that of the M2 but the anteroloph is shorter and joins the elongated anterior arm of the protocone with a right angle. The sinus is wider and reaches the middle of the occlusal surface and the synclines are shorter, synclines II and IV being the longest;

- A damaged and worn right tooth possibly a P4 (or M1/2) shows a disorganized pattern. The protoloph is transverse but the metaloph is interrupted, its labial part bending to the posteroloph. The mesoloph is not obvious but seems interrupted, partly parallel to the protoloph and fused with the paracone. The entoloph is interrupted behind the mesoloph.

\section{DISCUSSION}

The two teeth found in Möhren 20 display a mixture of morphological features known in Eomys from
Early Oligocene with features that were previously known only since the late Oligocene.

Some features are close to Eomys such as: the brachyodont and bunodont teeth with the rounded lingual tubercles and transverse crests joining the anterior part of the protocone and hypocone. Long mesolophs are known only in more recent Eomys.

Other features are observed for the first time in the Early Oligocene, the buno-lophodont pattern with elongated paracone and metacone more or less fused within the transverse crests, the long synclines resemble Pseudotheridomys Schlosser, 1926. However the connection of the protoloph with the anterior part of the protocone indicates without doubt that the teeth do not belong to Pseudotheridomys where the protoloph always joins the posterior part of the protocone; it is also generally the case for Eomyodon Engesser, 1987 where the protocone is compressed and obliquely directed antero-labially and where the interruption of the entoloph takes place before the mesoloph. The greater similarity is with the genus Asianeomys Wu, Meng, Ye \& Ni, 2006 from the late Oligocene/Early Miocene of China (Wu et al. 2006) and especially with $A$. fahlbuschi Wu, Meng, Ye \& Ni, 2006, with its long mesolophs fused with the paracone. Asianeomys fahlbuschi is however smaller, also some clear difference can also be observed as the mesoloph connects directly to the protocone.

It is noteworthy that, unfortunately, no lower molars with correspondant morphology are associated with the upper ones in Möhren 20. However, we know from Asianeomys that the upper and lower molars of eomyids can present a completely different pattern. Consequently we can hypothesize that the lower molars of this taxon could present a pattern more similar to Eomys, making it difficult to differentiate from the previously described Eomys sp.

Considering the little material known from Möhren 20 and the clear differences of upper molars with all the eomyids genera known up to now, we propose here that this taxon is a new genus of Eomyidae and we let the nomenclature open until the discovery of new material in this locality or another. 


\section{EVOLUTIONARY HISTORY OF THE FIRST WESTERN EUROPEAN EOMYIDS}

The study of the oldest Western European eomyids gives a new insight into their, previously poorly known, Early Oligocene history. New and abundant materials from Germany, France and Spain, from MP 21 to MP 24 levels, demonstrate, as soon as the MP 21 level following the "Grande Coupure", the occurrence of several species of different sizes instead of the sole and minute Eomys antiquus.

\section{VARIETY OF SPECIES}

Three species are now known in the MP 21 level: Eomys antiquus is the most abundant and the most widely distributed; this makes it possible, for the first time, to get an appraisal of the size and morphological intraspecific variabilities, which are very large. But in Germany, two other larger species are represented: Eomyidae gen. et sp. indet. and Eomys sp. According to the present knowledge, the two large species are only known in two German localities (perhaps also in Hoogbutsel) and neither seem to persist later nor to expand to other European countries. The hypothesis of the Rhine graben acting as a barrier (Schmidt-Kittler \& Vianey-Liaud 1975) could be put forward but it does not take into account the large expansion of the smaller species. Another explanation could be that the larger species did not succeed and disappeared rapidly as is the case for the arrival and rapid disappearance of the Lagomorpha in the MP 21-22 level.

Later in the Early Oligocene of France and Spain (MP 23-24) three species are recognized: Eomys aff. E. antiquus, Eomys aff. E. zitteli and Eomys minor. We think that Eomys aff. E. antiquus is likely derived from $E$. antiquus, its morphology and mesodonty being similar to specimens from the earlier levels, but slight differences in the size of teeth and some derived morphological characteristics indicate a higher level of evolution. The two other species are clearly different from the species described in the very Early Oligocene German localities, thus suggesting that they have no relationship with them; moreover the Saint-Martin-de-Castillon stratified levels yielded $E$. aff. E. zitteli in the older localities whereas $E$. aff. E. antiquus exists in the upper levels; this excludes that $E$. zitteli could derive from $E$. antiquus and indicates that the two species represent different lineages.

All these findings demonstrate that Western European eomyids were significant components of the migration following the "Grande Coupure". However, as E. zitteli and E.minor have hitherto not been found in the earliest Oligocene levels but only later, the appearance of different species not clearly related to the earlier species or between them, refutes also the hypothesis of the single arrival of a unique species giving rise to later taxa by repetitive cladogenesis (Fahlbusch 1973; Comte \& VianeyLiaud 1987). Two different hypothesis can be put forward: 1) either the ancestors of these species exist but, as the localities of the earliest Oligocene are not very numerous and not very rich, rare species have not been discovered; or 2) several spreading events occurred throughout MP 22-24 as could be indicated by the fact that new genera (as well in cricetids as in soricids) appeared, in almost every level of the Early Oligocene, suggesting the hypothesis of more or less continuous arrivals, even before the important change of the MP 25-26 level (Comte \& Vianey-Liaud 1989; Legendre et al. 1991)

If the diversification of the eomyids is integrated in the general evolution of the Oligocene mammalian faunas (Legendre et al. 2006), we can observe that between the main immigration event of the "Grande Coupure" (between MP 20 and MP 21) and a second important origination phase, correlated to the transition Early/late Oligocene (between MP 24 and MP 25), the arrival of taxa are not null. They reach, in MP 22-24, 28-30\% of the entire fauna: however, at the moment, their origin is not well understood.

\section{ORIGIN OF THE SPECIES}

Whereas eomyids are known in the Asian and American continents since the middle Eocene (Wang 2002; Dawson 2003), they seem to appear in Western Europe only at the beginning of the Oligocene, in relation with the "Grande Coupure" event. If one assumes that the datings of the localities are correct, this late appearance of eomyids in Europe is still to be explained. First, the climatic event due to the settlement of a permanent Antarctic ice sheet that 
occurred across the Eocene/Oligocene boundary (Flower \& Chisholm 2006) has probably affected species distribution and could explain the triggering of migration events. In this case, the geographical context may also have played a major role, indeed marine corridors linking Tethys domains with the Arctic and Atlantic oceans until the late Eocene (Rögl 1998; Meulenkamp \& Sissingh 2003) are likely to limit the distribution of species. Since the late Eocene, the tectonic evolution and the general regional uplift in northern Europe (Meulenkamp \& Sissingh 2003) may have contributed to open land connections with Asian continent and thus indirectly with North America.

The origin of European eomyids was previously considered as a single migration event from late Eocene or Early Oligocene of North America where eomyids were abundant in the fossil record, whereas they were still poorly known in Asia (Fahlbusch 1973, 1979; Comte \& Vianey-Liaud 1989; Vianey-Liaud 1985 contra Engesser 1987, who emphasized that certainly the history of early eomyids in Europe was not simple).

The undescribed eomyid genus found in Möhren 20 demonstrates, however, some morphological affinities with the late Oligocene/Early Miocene species of Asianeomys, recently described from China; it is presently impossible to decide if it is derivable from an European Eomys (as thought by Wu et al. 2006), or, more likely if unknown late Eocene Asian eomyid gave rise to it. Anyway, this observation now leads us to consider the Asian origin of European eomyids as a potential hypothesis, considering that, up to the present day, no similar morphological pattern has been described among North American eomyids. However this hypothesis has to be further tested with more comparisons between Asiatic and European material. Regarding this problematic the discovery of new eomyids in the Late Eocene/Early Oligocene of Asia will certainly be the key to clarify the evolutionary history of eomyids in Eurasia.

Nevertheless, the better knowledge we have now on eomyid diversity in the Early Oligocene of Europe allows us to undertake further systematic comparisons in order to better understand their evolutionary modalities and to establish a new phylogeny for the family that will be the next step toward the understanding of eomyid evolution and distribution over the holarctic domain.

\section{CONCLUSIONS}

The family Eomyidae appears in Europe after the "Grande Coupure", at the beginning of the Oligocene. In this study new material from the earliest Oligocene of southern Germany has been described, including Eomys antiquus, Eomys sp., and an undetermined genus, probably new, Eomyidae gen. et sp. indet. The latter is especially interesting as Eomys was the only genus of eomyid known in the Early Oligocene of Europe until now. So far, this new genus has not been found in younger localities of Germany and seems to be restricted to the very Early Oligocene. However it is noteworthy that if, as proposed by Legendre (1987), Möhren 13 and 20 are late Eocene these eomyids might be the first ones arriving in Europe along the Cricetids from Romania (Baciu \& Hartenberger 2001), then Eomyidae gen. et sp. indet and Eomys sp. would be restricted to the late Eocene.

In the Early Oligocene of France and Spain the species Eomys aff. E. antiquus, E. aff. E. zitteli and $E$. minor are recognized. Based on their morphology, E. aff. E. zitteli and E. minor seem unlikely derived from the older species known in France and Germany suggesting they could be either immigrant species arrived in Europe later in the Early Oligocene or are very rare species not yet found in the earlier levels.

More generally our results emphasise the already high diversity of eomyids in the Early Oligocene leading to consider a more complex evolutionary history than previously proposed.

Concerning the origin of European eomyids, the probably new eomyid genus found in southern Germany shows some morphological affinities with the late Oligocene/Early Miocene species of Asianeomys from China. Even though the relationship between this Chinese genus and the European eomyids remains unclear, this observation supports the hypothesis of an Asian origin of European eomyids considering that so far no 
similar morphology has been described among North American eomyids.

\section{Acknowledgements}

For this study OM acknowledges financial support from DAAD (Deutscher Akademischer Austausch Dienst). The authors want to thank Jerome Prieto and Bettina Schenk (University of Munich), Arlette Armand (University of Lyon) and Alain Barreau (University of Nantes) for their taking pictures on the scanning electron microscope. We thank Gudrun Daxner-Höck (Natural History Museum of Vienna) and Monique Vianey-Liaud (University Montpellier II) for their welcome to their institutions to study the material of Eomyidae. We want also to express our sincere thanks to Wu Wenyu who red a previous version of this paper and contributed to improve this study through instructive discussions. This publication has also been improved by helpful comments by Loïc Costeur, four anonymous reviewers, and David Hone who kindly helped to improve the English text.

\section{REFERENCES}

AYMARD A.1853. - Catalogue du matériel d'Aymard, in Pictet F. J. (ed.), Traité de Paléontologie. 2nd ed. J. B. Baillière, Paris, $584 \mathrm{p}$.

Baciu C. \& Hartenberger J.-L. 2001. - Un exemple de corrélation marin-continental dans le Priabonien de Roumanie. Remarques sur la Grande Coupure. Comptes rendus de l'Académie des Sciences, série 2, 333: 441-446.

BIOCHROM'97 1997. - Synthèse et tableaux de corrélations, in Aguilar J.-P., Legendre S. \& Michaux J. (eds), Actes du Congrès BiochroM'97, Inst. Montpellier, Mémoires et travaux de l'EPHE 21: 769-805.

BLACK C. C. 1965. - Fossil mammals from Montana. Pt. 2. Rodents from the Early Oligocene Pipestone springs local fauna. Annals of the Carnegie Museum 38: 1-48.

Comte B. \& Vianey-Liaud M. 1987. — New Eomyidae Paleogene localities in Western Europe. Comptes rendus de l'Académie des Sciences, série 2, 304 (15): 951-955.

Comte B. \& Vianey-Liaud M. 1989. - Eomyidae (Rodentia) de l'Oligocène d'Europe occidentale. Palaeontographica 209A: 33-91.

DAWSON M. R. 2003. - Paleogene rodents of Eurasia, in Reumer J. W. F. \& Wessels W. (eds), Distribution and migration of Tertiary mammals in Eurasia. A volume in honour of Hans de Bruijn. Deinsea 10: 97-125.

Ducreux J. L., Hugueney M. \& Truc G. 1985. - La formation des Calcaires et Lignites de Sigonce (Oligocène moyen, bassin de Forcalquier, Alpes-de-HauteProvence) : datation à l'aide des mammiferes; reconstitution des milieux de dépôts. Geobios 18: 109-114.

Emry R. J., Wang B., TJutKova L. A. \& LuCAS S. G. 1997. - A late Eocene Eomyid rodent from the Zaysan basin of Kazakhstan. Journal of Vertebrate Paleontology 17: 229-234.

Engesser B. 1987. - New Eomyidae, Dipodidae and Cricetidae (Rodentia, Mammalia) of the lower freshwater Molasse of Switzerland and Savoy. Eclogae Geologicae Helvetiae 80: 943-994.

ENGESSER B. 1990. — Die Eomyidae (Rodentia, Mammalia) der Molasse der Schweiz und Savoyens. Systematik und Biostratigraphie. Schweizerische Paläontologische Abhandlungen 112: 1-144.

ENGESSER B. 1999. - Family Eomyidae, in RÖSSNER G. E. \& Heissig K. (eds), The Miocene Land Mammals of Europe. Verlag Dr Friedrich Pfeil, Munich: 319-335.

ENGESSER B. \& MÖDden C. 1997. - A new version of the biozonation of the lower freshwater molasse (Oligocene and Agenian) of Switzerland and Savoy on the basis of fossil mammals, in AGUILAR J.-P., Legendre S. \& MichauX J. (eds), Actes du Congrès BiochroM'97, Inst. Montpellier, Mémoires et travaux de l'EPHE 21: 475-499.

FAHLBUSCH V. 1970. — Populationsverschiebungen bei tertiären Nagetieren, eine Studie an oligozänen und miozänen Eomyidae Europas. Verlag der bayerischen Akademie der Wissenschaften 145: 7-136.

FAHLBUSCH V. 1973. - Die stammgeschichtlichen Beziehungen zwischen den Eomyiden (Mammalia, Rodentia) Nordamerikas und Europas. Mitteilungen der Bayerischen Staatssammlungs für Paläontologie und historische Geologie 13: 141-175.

FaHLBUSCH V. 1979. — Eomyidae-Geschichte einer Säugetierfamilie. Paläontologische Zeitschrift 53: 88-97.

FEJFAR O. 1987. - A Lower Oligocene mammalian fauna from Detan and Dverce NW Bohemia, Czechoslovakia, in SCHMIDT-KITTLER N. (ed.), International symposium on mammalian biostratigraphy and paleoecology of the European Paleogene Mainz, February 18th-21st 1987. Münchner Geowissenschaftliche Abhandlungen A10: 253-264.

Flower B. P. \& ChISHOLM K. E. 2006. - 3. Magnetostratigraphic calibration of the late Oligocene climate transition, in Tiedemann R., Mix A. C., Richter C. \& Ruddiman W. F. (eds), Proceedings of the Ocean Drilling Program, Scientific Results 202: 1-15.

FrEUDENBERG H. 1941. — Die oberoligocänen Nager von Gaimersheim bei Ingolstadt und ihre Verwandten. Palaeontographica 92 (A): 99-164. 
Freudenthal M., Lacomba J. I., Martinez-Salanova J. \& SACRISTAN A. 1990. - Nueva sucesion de niveles con micromamíferos en el Oligoceno de Montalban (Prov. Teruel, Espana). Acta salmanticensia 68: 133-140.

HEISSIG K. 1987. — Changes in the rodent and ungulate fauna in the Oligocene fissure fillings of Germany, in SCHMIDT-KITTLER N. (ed.) International symposium on mammalian biostratigraphy and paleoecology of the European Paleogene Mainz, February 18th-21st 1987. Münchner Geowissenschaftliche Abhandlungen A10: 101-108.

Hugueney M. \& Mödden C. 1996. - The biostratigraphical position of the Oligocene French fossil localities Saint-Martin-de-Castillon (Apt basin) and Vialenc (Aurillac basin) based on Issiodoromyini (Mammalia, Rodentia, Theridomyidae). Eclogae Geologicae Helvetiae 89: 1345-1362.

LAVOCAT R. 1952. - Révision des faunes de Mammiferes oligocènes d'Auvergne et du Velay. Sciences et Avenir, Paris, $153 \mathrm{p}$.

LEGENDRE S. 1987. — Les immigrations de la «Grande Coupure» sont-elles contemporaines en Europe occidentale, in SCHMIDT-KITTLER N. (ed.), International symposium on mammalian biostratigraphy and paleoecology of the European Paleogene Mainz, February 18th -21st 1987. Münchner Geowissenschaftliche Abhandlungen A10: 141-148.

Legendre S., Crochet J.-Y., Godinot M., HartenBerger J.-L., Marandat B., Remy J. A., Sige B., Sudre J. \& Vianey-Liaud M. 1991. - Évolution de la diversité des faunes de mammifères d'Europe occidentale au Paléogène (MP 11 à MP 30). Bulletin de la Société géologique de France 162 (5): 867-874.

Legendre S., Mourer-Chauvire C., Hugueney M., Maitre E., Sige B. \& Escarguel G. 2006. — Dynamique de la diversité des mammiferes et des oiseaux paléogènes du Massif Central (Quercy et Limagnes, France). Strata 1 (13): 275-282.

MeulenKamp J. E. \& Sissingh W. 2003. - Tertiary palaeogeography and tectonostratigraphic evolution of the Northern and Southern Peri-Tethys platforms and the intermediate domains of the African-Eurasian convergent plate boundary zone. Palaeogeography, Palaeoclimatology, Palaeoecology 196: 209-228.

Reichenbacher B. \& Philippe M. 1997. - Otoliths of Oligocene Teleostei of the Apt Basin (Vaucluse, France). Neues Jahrbuch für Geologie und Paläontologie Abhandlungen 203: 391-423.

RöGL F. 1998. - Palaeogeographic considerations for Mediterranean and Paratethys Seaways (Oligocene to Miocene). Annalen des Naturhistorischen Museum in Wien 99A: 279-310.

Schmidt-Kittler N., Godinot M., Franzen J. L., Hooker J. J., Legendre S., Brunet M. \& VianeyLIAUD M. 1987. - European reference levels and correlation tables, in SCHMIDT-KITTLER N. (ed.), International symposium on mammalian biostratigraphy and paleoecology of the European Paleogene Mainz, February 18th-21st 1987. Münchner Geowissenschaftliche Abhandlungen, Munich A10: 13-31.

SCHMidT-KitTler N. \& Vianey-Liaud M. 1975. Relations entre les faunes de rongeurs d'Allemagne du Sud et de France pendant l'Oligocène. Comptes rendus de l'Académie des Sciences de Paris D 281: 511-514.

STEHLIN H. G. 1910. - Remarques sur les faunules de mammifères des couches Éocènes et Oligocènes du bassin de Paris. Bulletin de la Société géologique de France 9: 488-520.

ViANEY-Liaud M. 1985. — Possible evolutionary relationship among Eocene and Lower Oligocene rodents of Asia, Europe and North-America, in LUCKETT W. P. \& Hartenberger J.-L. (eds), Evolutionary relationships among rodents. A multidisciplinary Analysis. NATO Advanced Study Institute Series 92 (A): 277-309.

WANG B.-Y. 2002. - Discovery of late Oligocene Eomyodon (Rodentia, Mammalia) from the Danghe area, Gansu, China. Vertebrata PalAsiatica 40:139-145.

WANG B.-Y. \& EMRY R. J. 1991. — Eomyids (Rodentia: Mammalia) from the Oligocene of Nei Mongol, China. Journal of Vertebrate Paleontology 11: 370-377.

Wu W.-Y., Meng J., Ye J. \& Ni X.-J. 2006. — The first finds of eomyids (Rodentia) from the late OligoceneEarly Miocene of the Northern Junggar Basin, China. Beiträge zur Paläontologie 30: 469-479. 


\section{APPENDIX}

FIG. A1. - Morphological variability of Early Oligocene small and medium sized Eomys Schlosser, 1884 populations, P4. N, number of individuals observed. Variability is observed on the following morphological features: I, presence of a lingual anteroloph; II, development of the labial anteroloph; III, development of the mesoloph; IV, entoloph; V, protoloph; VI, posteroloph. Abbreviations for localities: Mö 13, Möhren 13 (E. antiquus); Mö 20, Möhren 20 (E. antiquus (Aymard, 1853)); Montb, Montalban (E. aff. E. antiquus); St M.C, SaintMartin-de-Castillon C (E. aff. E. antiquus); St M.F, Saint-Martin-de-Castillon F (E. aff. E. antiquus); St M.J, Saint-Martin-de-Castillon J (E. aff. E. zitteli Schlosser, 1884);.

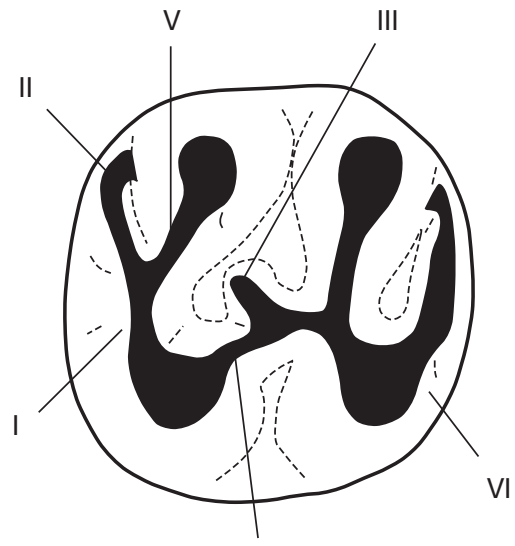

IV

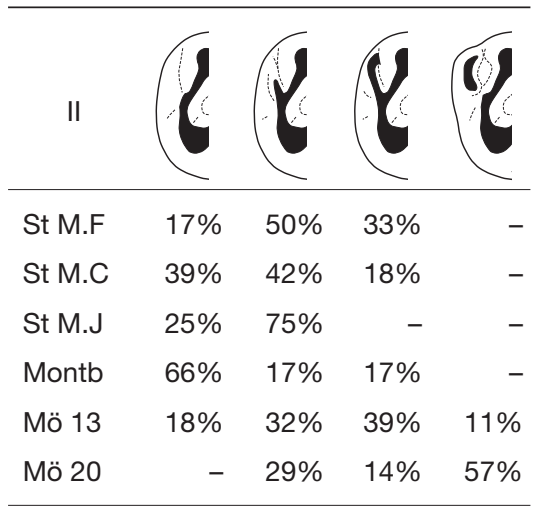

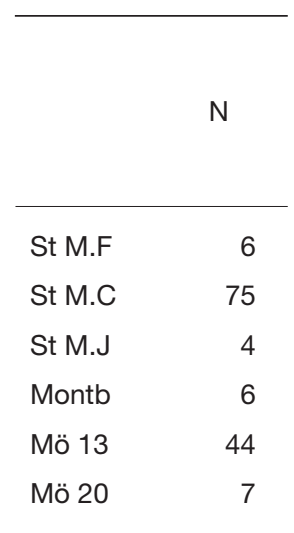

\begin{tabular}{lrrr}
\hline & \\
\hline St M.F & $67 \%$ & $33 \%$ & - \\
St M.C & $89 \%$ & $8 \%$ & $3 \%$ \\
St M.J & $25 \%$ & $50 \%$ & $25 \%$ \\
Montb & $67 \%$ & $33 \%$ & - \\
Mö 13 & $73 \%$ & $23 \%$ & $4 \%$ \\
Mö 20 & $71 \%$ & $29 \%$ & - \\
\hline
\end{tabular}

III
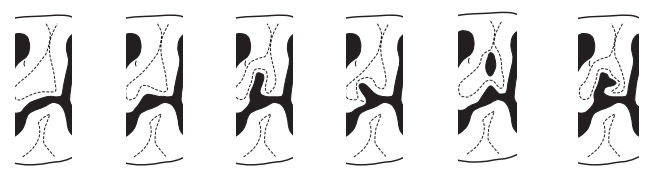

St M.F $33 \%$

St M.C $\quad 23 \%$

St M.J

$$
\text { - } \quad-\quad 80 \%
$$
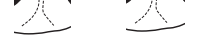

Montb

$-$

Mö $13 \quad 16 \%$

Mö 20

$29 \%$

$17 \%$

$17 \%$

$21 \%$

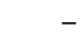

$4 \%$

- $20 \%$

\section{$33 \%$}

$29 \%$

$32 \%$

$29 \%$

$13 \%$
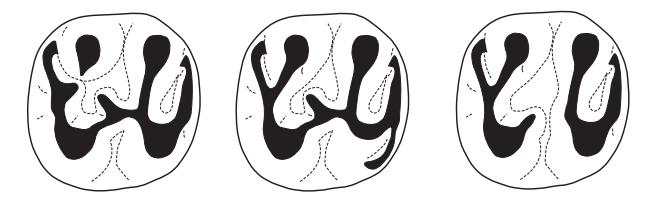

St M.C

St M.J

Mö 13

Mö 20
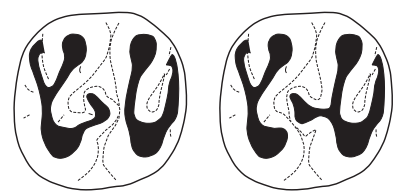

Rare morphologies

(number of teeth)

21

$-$

3

1

2

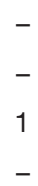

1

1 
FIG. A2. - Morphological variability of Early Oligocene small and medium sized Eomys Schlosser, 1884 populations, M1/2. N, number of individuals observed. Variability is observed on the following morphological features: I, development of the mesoloph; II, development of the lingual anteroloph; III, connection between the anterolophs and the protocone; IV, presence of a short crest in the lingual sinus; V, entoloph. Abbreviations for localities: see Figure A1.

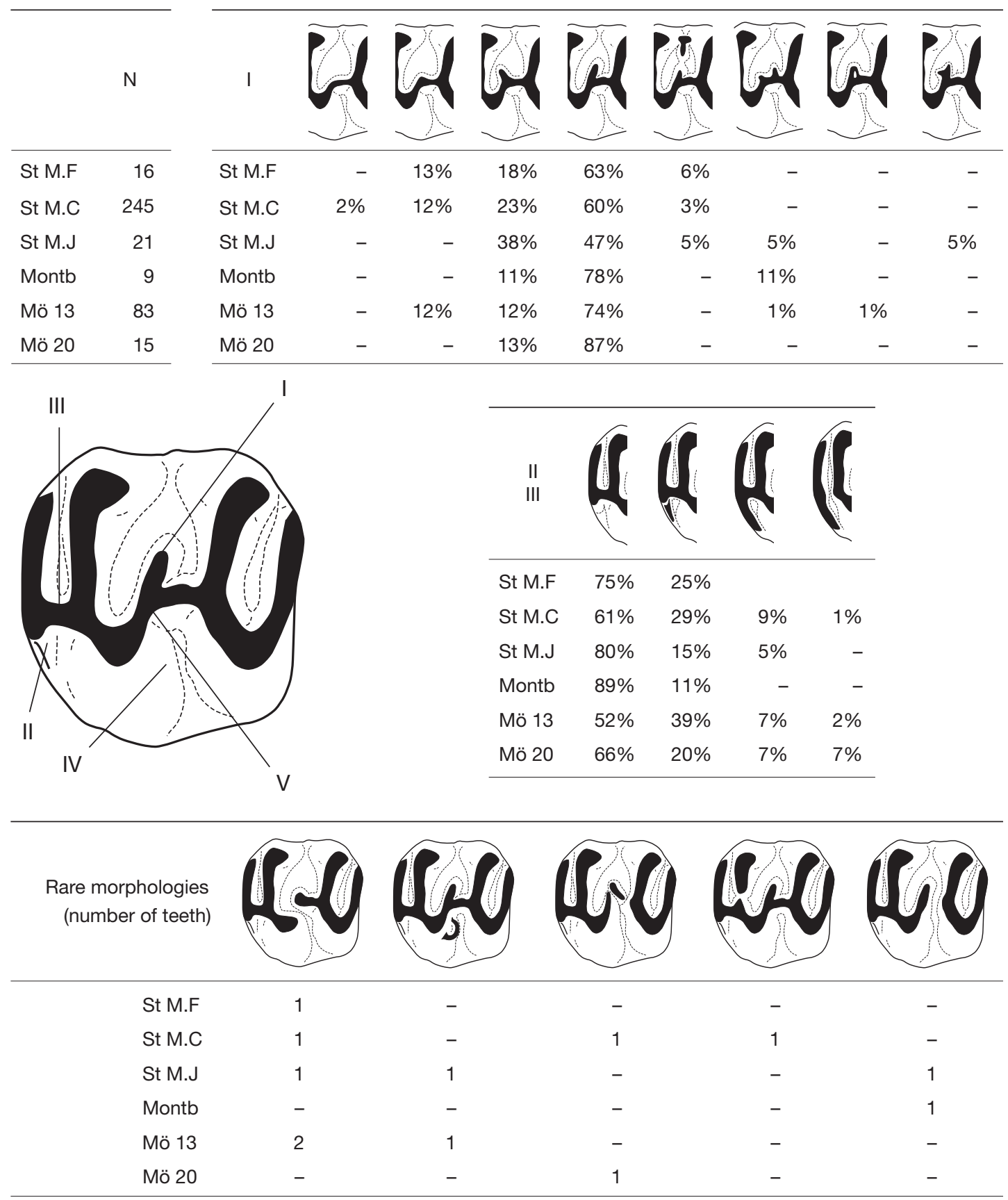


FIG. A3. - Morphological variability of Early Oligocene small and medium sized Eomys Schlosser, 1884 populations, M3. N, number of individuals observed. Variability is observed on the following morphological features: I, development of the metaloph; II, development of a mesoloph starting from the metaloph; III, presence of a posterior spur starting from the metaloph; IV, development of the lingual anteroloph; V, protoloph; VI, posterior spur on the protoloph. Abbreviations for localities: see Figure A1.

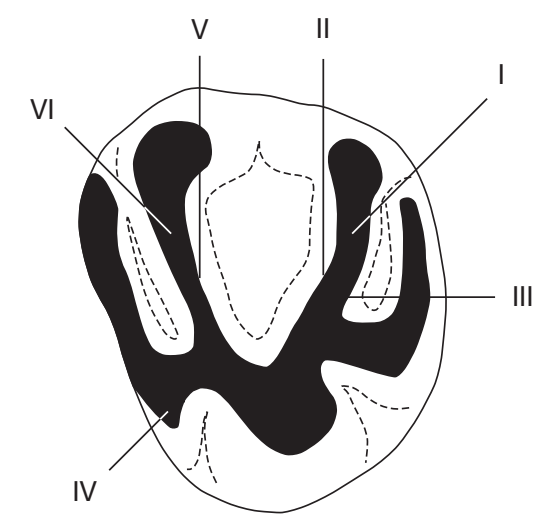

\begin{tabular}{lr}
\hline & N \\
& \\
\hline St M.F & 2 \\
St M.C & 45 \\
St M.J & 2 \\
Montb & 2 \\
Mö 13 & 20 \\
Mö 20 & 3
\end{tabular}

\begin{tabular}{lrrr}
\hline & \\
\hline St M.F & - & $50 \%$ & $50 \%$ \\
St M.C & - & $7 \%$ & $93 \%$ \\
St M.J & - & - & $100 \%$ \\
Montb & - & - & $100 \%$ \\
Mö 13 & $10 \%$ & $20 \%$ & $70 \%$ \\
Mö 20 & $33 \%$ & - & $67 \%$ \\
\hline
\end{tabular}

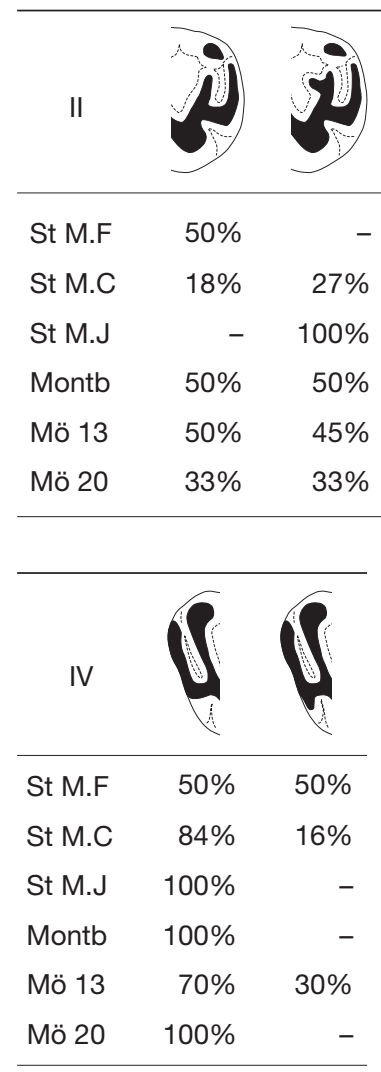

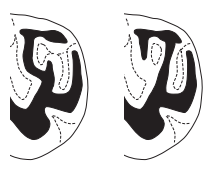

\begin{tabular}{lrrr}
\hline III & & & \\
& & & \\
St M.F & $50 \%$ & - & $50 \%$ \\
St M.C & $62 \%$ & $36 \%$ & $2 \%$ \\
St M.J & - & $100 \%$ & - \\
Montb & $50 \%$ & $50 \%$ & - \\
Mö 13 & $90 \%$ & $5 \%$ & $5 \%$ \\
Mö 20 & $100 \%$ & - & - \\
\hline
\end{tabular}

Rare morphologies

(number of teeth)
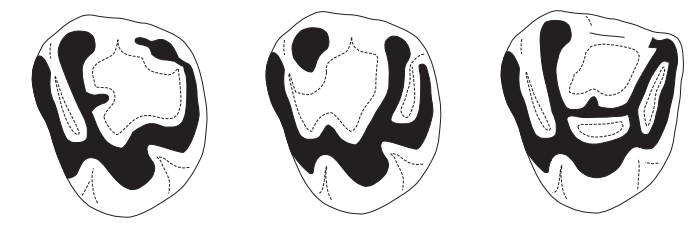

St M.C

2

Montb

Mö 13
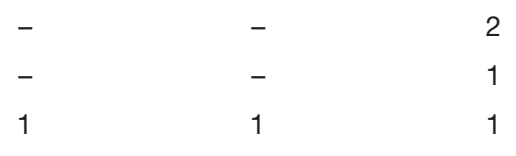
FIG. A4. - Morphological variability of Early Oligocene small and medium sized Eomys Schlosser, 1884 populations, p4. N, number of individuals observed. Variability is observed on the following morphological features: I, presence of an anteroconid; II, development of a metalophid between the metaconid and the protoconid; III, development of the mesolophid; IV, development of the posterolophid. Abbreviations for localities: see Figure A1.

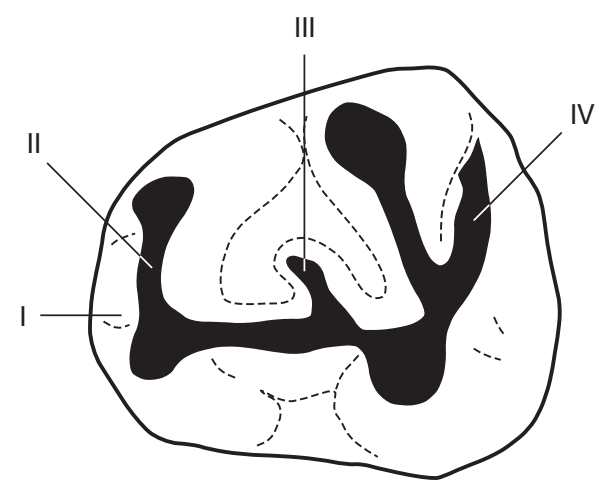

\begin{tabular}{lr}
\hline & $N$ \\
& \\
\hline St M.F & 4 \\
St M.C & 65 \\
St M.J & 6 \\
Montb & 3 \\
Mö 13 & 47 \\
Mö 20 & 6 \\
\hline
\end{tabular}

\begin{tabular}{lrrr}
\hline & \\
St M.F & $25 \%$ & - & $75 \%$ \\
St M.C & - & $17 \%$ & $83 \%$ \\
St M.J & - & $20 \%$ & $80 \%$ \\
Montb & $33 \%$ & $33 \%$ & $33 \%$ \\
Mö 13 & - & $9 \%$ & $91 \%$ \\
Mö 20 & - & $50 \%$ & $50 \%$ \\
\hline
\end{tabular}

\begin{tabular}{|c|c|c|c|c|}
\hline St M.F & - & - & $100 \%$ & \\
\hline St M.C & $15 \%$ & $23 \%$ & $58 \%$ & \\
\hline St M.J & $33 \%$ & - & $67 \%$ & \\
\hline Montb & - & $33 \%$ & $67 \%$ & \\
\hline Mö 13 & $4 \%$ & $38 \%$ & $51 \%$ & \\
\hline Mö 20 & - & - & $100 \%$ & \\
\hline IV & & & & \\
\hline St M.F & - & $25 \%$ & $75 \%$ & - \\
\hline St M.C & $10 \%$ & $51 \%$ & $39 \%$ & - \\
\hline St M.J & - & - & $100 \%$ & - \\
\hline Montb & - & - & $100 \%$ & - \\
\hline Mö 13 & $2 \%$ & $79 \%$ & $17 \%$ & $2 \%$ \\
\hline Mö 20 & - & $80 \%$ & $20 \%$ & - \\
\hline
\end{tabular}

\section{Rare morphology} (number of teeth)

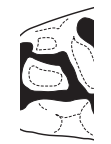

\section{II}
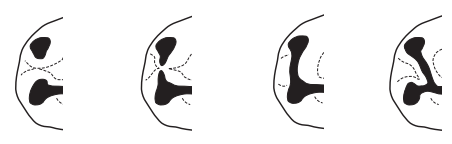

\begin{tabular}{lllll}
\hline St M.F & - & - & $100 \%$
\end{tabular}

St M.C

$-\quad 8 \%$

$89 \%$

$3 \%$

St M.J

Montb

$$
-
$$

$-\quad 33 \%$

- $100 \%$

Mö 13

$32 \%$

$47 \%$

$67 \%$

Mö 20 - $\quad 50 \%$

$17 \%$

$4 \%$

- $\quad 50 \%$


FIG. A5. - Morphological variability of Early Oligocene small and medium sized Eomys Schlosser, 1884 populations, m1/2. N, number of individuals observed. Variability is observed on the following morphological features: I, development of the mesolophid; II, development of the labial anterolophid; III, connection of the anterolophids. Abbreviations for localities: see Figure A1.

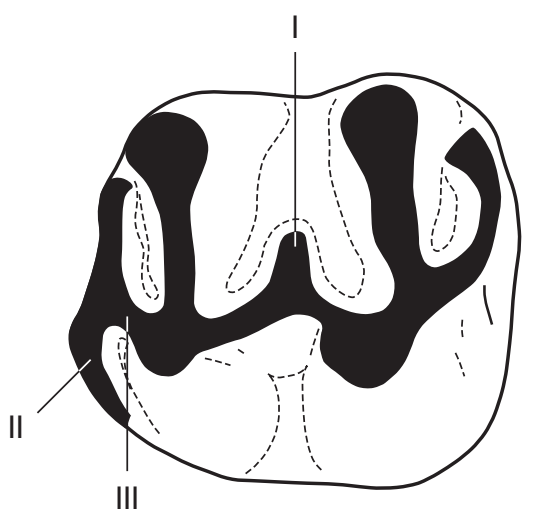

III

\begin{tabular}{lr}
\hline & N \\
& \\
\hline St M.F & 15 \\
St M.C & 239 \\
St M.J & 21 \\
Montb & 6 \\
Mö 13 & 90 \\
Mö 20 & 17 \\
\hline
\end{tabular}

\begin{tabular}{lrrr}
\hline & \\
\hline St M.F & - & - & $100 \%$ \\
St M.C & $1 \%$ & $12 \%$ & $87 \%$ \\
St M.J & - & $13 \%$ & $87 \%$ \\
Montb & - & - & $100 \%$ \\
Mö 13 & $4 \%$ & $17 \%$ & $79 \%$ \\
Mö 20 & $6 \%$ & $23 \%$ & $71 \%$ \\
\hline
\end{tabular}

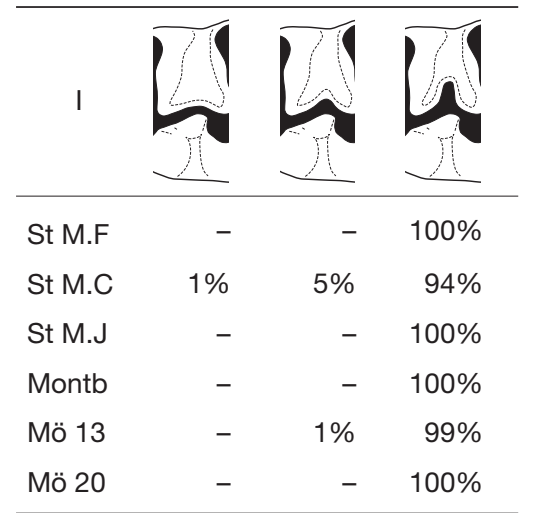

\begin{tabular}{lrrr}
\hline IIII & \\
\hline St M.F & $13 \%$ & $74 \%$ & $13 \%$ \\
St M.C & $37 \%$ & $47 \%$ & $16 \%$ \\
St M.J & $59 \%$ & $18 \%$ & $23 \%$ \\
Montb & $66 \%$ & $17 \%$ & $17 \%$ \\
Mö 13 & $60 \%$ & $31 \%$ & $9 \%$ \\
Mö 20 & $76 \%$ & $6 \%$ & $18 \%$ \\
\hline
\end{tabular}

Rare morphologies

(number of teeth)

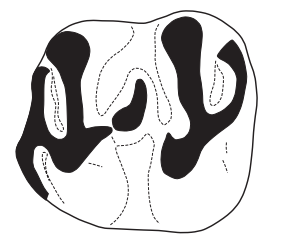


FIG. A6. Morphological variability of Early Oligocene small and medium sized Eomys Schlosser, 1884 populations, m3. N, number of individuals observed. Variability is observed on the following morphological features: I, development of the labial anterolophid; II, development of the mesolophid; III, connection of the anterolophids; IV, posterior spur on the mesolophid; V, ectolophid; VI, spur starting from the posterolophid. Abbreviations for localities: see Figure A1.

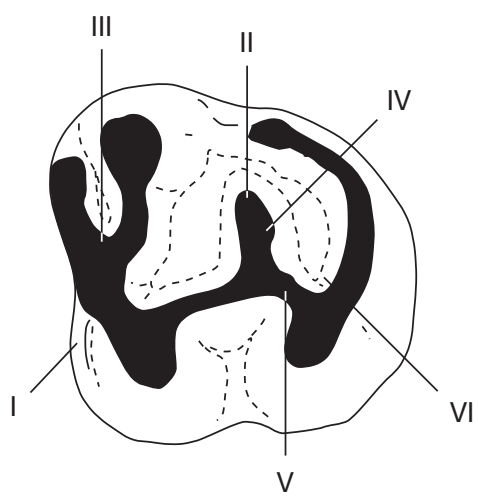

$\mathrm{N}$

\begin{tabular}{lr}
\hline St M.F & 8 \\
St M.C & 100 \\
St M.J & 7 \\
Montb & 2 \\
Mö 13 & 53 \\
Mö 20 & 9 \\
\hline
\end{tabular}

\begin{tabular}{lrrr}
\hline & - \\
St M.F & - & - & $100 \%$ \\
St M.C & $1 \%$ & $40 \%$ & $59 \%$ \\
St M.J & - & $14 \%$ & $86 \%$ \\
Montb & - & $50 \%$ & $50 \%$ \\
Mö 13 & $2 \%$ & $6 \%$ & $92 \%$ \\
Mö 20 & - & $11 \%$ & $89 \%$ \\
\hline
\end{tabular}

\begin{tabular}{lrrr}
\hline III & \\
St M.F & $25 \%$ & $75 \%$ & - \\
St M.C & $11 \%$ & $80 \%$ & $9 \%$ \\
St M.J & - & $86 \%$ & $14 \%$ \\
Montb & $50 \%$ & $50 \%$ & - \\
Mö 13 & $26 \%$ & $40 \%$ & $34 \%$ \\
Mö 20 & $12 \%$ & $44 \%$ & $44 \%$ \\
\hline
\end{tabular}

\begin{tabular}{lrrr}
\hline & - & $38 \%$ & $62 \%$ \\
\hline St M.F & $1 \%$ & $44 \%$ & $55 \%$ \\
St M.C & - & $14 \%$ & $86 \%$ \\
St M.J & - & $50 \%$ & $50 \%$ \\
Montb & - & $96 \%$ & $4 \%$ \\
Mö 13 & - & $100 \%$ & - \\
Mö 20 & & & \\
\hline
\end{tabular}

\begin{tabular}{lrrrr}
\hline & \\
St M.F & $87 \%$ & $13 \%$ & - & - \\
St M.C & $93 \%$ & $5 \%$ & - & $2 \%$ \\
St M.J & $86 \%$ & $14 \%$ & - & - \\
Montb & $50 \%$ & $50 \%$ & - & - \\
Mö 13 & $92 \%$ & $2 \%$ & $6 \%$ & - \\
Mö 20 & $89 \%$ & $11 \%$ & - & - \\
\hline
\end{tabular}

Rare morphologies (number of teeth)
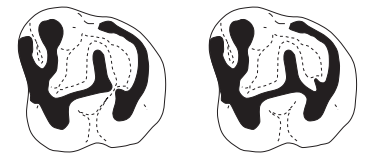

\section{4}

1
1 